\section{Challenging Cognitive Construals: A Dynamic Alternative to Stable Misconceptions}

\author{
Julia S. Gouvea ${ }^{\dagger * *}$ and Matt R. Simon ${ }^{\dagger}$ \\ ${ }^{\dagger}$ Department of Education and ₹Department of Biology, Tufts University, Medford, MA 02155
}

\begin{abstract}
In biology education research, it has been common to model cognition in terms of relatively stable knowledge structures (e.g., mental models, alternative frameworks, deeply held misconceptions). For example, John D. Coley and Kimberly D. Tanner recently proposed that many student difficulties in biology stem from underlying cognitive frameworks called cognitive construals (CBE-Life Sciences Education, 11[3], 209-215 [2012]; CBE-Life Sciences Education, 14[1], ar8 [2015]). They argued that three such frameworks-teleology, anthropocentrism, and essentialism-cause undergraduate students to hold a range of misconceptions about the biological world. Our purpose in this article is to present an alternative perspective that considers student thinking to be dynamic and context sensitive. Using the example of cognitive construals, we argue that a dynamic perspective creates a burden of proof for claims of cognitive stability-to demonstrate that patterns of thinking are indeed stable across contexts. To illustrate our argument, we report on the results of a study designed to explore the stability of students' apparent teleological, anthropocentric, and essentialist thinking. Our results are inconsistent with framework models. We propose instead that response patterns stem from students' context-specific interpretations of the statements, consistent with dynamic models of cognition. Building on these preliminary findings, we discuss the implications of a dynamic view of cognition for biology education research and biology instruction.
\end{abstract}

\section{INTRODUCTION}

A central challenge of education research is to understand why students sometimes make incorrect statements. In particular, to ask, what do these incorrect statements mean about how students think and learn? In biology education research, it has been common to describe students' cognition in terms of relatively stable cognitive frameworks (e.g., mental models, alternative frameworks, deeply held misconceptions) and to assume that expressions of incorrect ideas indicate flaws in students' cognitive frameworks.

In this article, we argue from an alternative perspective-that cognition is dynamic and sensitive to local contexts. ${ }^{1}$ This perspective allows for the possibility that expressions or endorsements of incorrect ideas do not necessarily mean that students hold those ideas in a stable cognitive framework. In fact, from a dynamic, context-sensitive perspective, instances of expressing incorrect ideas are insufficient evidence of underlying frameworks. Therefore, a dynamic perspective on cognition creates a burden of

\footnotetext{
${ }^{1}$ The debate between static and dynamic models of cognition is long-standing in the cognitive and learning sciences (for an overview, see Özdemir and Clark, 2007). More recently, this debate has moved into biology education research (e.g., see Maskiewicz and Lineback [2013] and the response by Leonard et al. [2014]). In arguing from the dynamic side of the debate, we align ourselves with prior work characterizing knowledge as composed of fine-grained elements that are contextually activated (see, most notably, Smith et al., 1994; Hammer, 1996).
}

Hannah Sevian, Monitoring Editor Submitted October 3, 2017; Revised March 15 2018; Accepted March 16, 2018

CBE Life Sci Educ June 1, 2018 17:ar34

DOI:10.1187/cbe.17-10-0214

*Address correspondence to: Julia S. Gouvea (Julia.gouvea@tufts.edu).

(C) 2018 Gouvea and Simon. CBE-Life Sciences Education () 2018 The American Society for Cell Biology. This article is distributed by The American Society for Cell Biology under license from the author(s). It is available to the public under an Attribution-Noncommercial-Share Alike 3.0 Unported Creative Commons License (http://creativecommons.org/licenses/ by-nc-sa/3.0)

"ASCB ${ }^{\circledR}$ " and "The American Society for Cell Biology ${ }^{\circledR "}$ are registered trademarks of The American Society for Cell Biology. 
proof for claims of cognitive stability: to claim that observed patterns of thinking are caused by stable underlying cognitive frameworks, researchers would need to demonstrate that students are in fact thinking in stable ways across contexts. More generally, we argue that cognitive models that include considerations of how context can influence cognition are useful, because they can explain observed patterns of variation and flexibility in student thinking that stable framework models cannot.

To illustrate our position, we apply a dynamic perspective to the problem of teleological, anthropocentric, and essentialist thinking in biology. We were first drawn to this problem through the work of Coley and Tanner $(2012,2015)$, who proposed that intuitive cognitive frameworks (what they call cognitive construals) could explain why students often make and agree with incorrect statements in biology. Coley and Tanner (2015) conducted a study in which they asked students whether or not they agreed with 12 statements that were teleological, anthropocentric, or essentialist and then asked students to explain their thinking. They found that many biology majors and nonmajors agreed with the incorrect statements and that they often used teleological, anthropocentric, or essentialist language when asked to explain their agreement. Coley and Tanner (2015) interpreted these data as evidence of underlying cognitive structures that are persistent and problematic for biology learning. They suggested that one reason we see so many misconceptions in undergraduate biology students' thinking is that students possess and apply flawed cognitive construal frameworks.

Coley and Tanner $(2012,2015)$ linked their claim to a longer trajectory of work in cognitive developmental psychology that has proposed the existence and prevalence of naïve intuitive biological frameworks. These intuitive frameworks are hypothesized to arise early in development through some combination of innate predispositions and early experiences. Once formed, intuitive frameworks are thought to function as cognitive defaults that are applied broadly to make sense of a range of phenomena. For example, Kelemen has argued that intuitive teleology - the tendency to view objects as existing to serve some function-is so dominant in the thinking of young children that they apply these frameworks "promiscuously" across a wide range of situations (Kelemen, 1999a,b,c). Kelemen and colleagues have also argued that teleological frameworks persist beyond childhood into adolescence and adulthood, when they continue to bias thinking (Kelemen and Rosset, 2009; Kelemen et al., 2012).

Building on this work, Coley and Tanner (2012, 2015) hypothesized that flawed intuitive frameworks-teleology, anthropocentrism, and essentialism-could be common features of undergraduate cognition. They described cognitive construal frameworks as persistent, difficult to change, and therefore problematic for biology instruction. Unless the underlying cognitive frameworks are corrected, they argued, instructors should continue to see patterns of problematic thinking among undergraduate students. Coley and Tanner (2015) have also suggested that instruction could be reinforcing rather than correcting these underlying modes of cognition (p. 16). If this is true, then correcting cognitive construals should be a central focus of instructional interventions in biology education.

As we will elaborate, coming from a dynamic perspective, we were skeptical of the interpretation that undergraduate students hold and apply cognitive construal frameworks. We do not disagree that students often use teleological, anthropocentric, and essentialist language in their explanations of the biological world; there is clear evidence that these modes of explanation are common (Tamir and Zohar, 1991; Keil, 1992; Kelemen, 1999a,b,c; Medin and Atran, 2004; Talanquer, 2010, 2013), even among experts (Keleman and Rosset, 2009; Kelemen et al., 2012). We do not dispute these patterns; however, we think alternative explanations for their causes are plausible and likely.

Consider, for example, that many biology students in Coley and Tanner's (2015) study agreed with the statement "Plants produce oxygen so that animals can breathe." Agreement with this statement could be interpreted as evidence of students holding a misconception based in teleological reasoning. That is, students could be thinking, as the statement implies, that the origin of oxygen production is driven by animals' needs. Further, this thinking could reflect a deeply held cognitive tendency to view structures in the world as goal or need driven. However, it is also possible that agreement does not stem from deeply held beliefs about teleological causality. Perhaps students did not even notice the flawed implication in the statement. Instead, students may have noticed a statement about plants producing oxygen (biologically accurate) and animals breathing it (also biologically accurate) and intended to endorse those relationships. When next asked to explain their thinking, we could imagine a student repeating the flawed implication in their explanation, writing, as Coley and Tanner reported, "Plants produce oxygen for all kinds of life forms to help fuel the reactions necessary for daily life." Once again, we can imagine students writing such a statement without intending to imply, or believing, that oxygen production is caused by the role it plays in supporting respiration in other organisms. Perhaps in writing the above statement, the student only meant to emphasize the important role of plants as oxygen producers.

We do not know for sure what students were actually thinking when they chose to agree with these statements, and that is our point. We were skeptical of Coley and Tanner's study, as well as much of the work in cognitive developmental psychology upon which it built, because we did not see the data as sufficient to make strong inferences about the general nature of students' cognition. To make the difference between observed data patterns and inference clear, we will distinguish between construal-based formulations and construal-based cognition (as in Zohar and Ginossar, 1998). Construal-based formulations refer to spoken or written statements that communicate the logic of each construal; they are observable. Construal-based cognition refers to underlying patterns of thought; these patterns are inferred, not observed. This distinction is necessary, because, as we elaborate later, construal-based formulations often imply rather than explicitly articulate the logic that makes them problematic, making agreement with them difficult to interpret. Furthermore, construal-based thinking, if applied appropriately, can also be correct and useful. It can be difficult to determine whether a person who expresses or endorses construal-based statements is attending to correct or problematic uses of the construal. To clarify this problem, we briefly elaborate on the differences between construal-based thinking and construal-based formulations for each of three construal types, identifying the challenges of making inferences about the former from the latter. 


\section{Teleological Thinking and Formulations}

One component of teleological thinking describes the tendency to view the world through the lens of function. When one encounters a novel artifact, this aspect of teleological thinking is useful, orienting a thinker to notice and respond to potential functions (i.e., scissors are for cutting). A functional lens can also be appropriately applied to biological traits. From the perspective of the organisms that possess them, traits like camouflage coloring, tall necks, or webbed toes have obvious functional utility. Noticing such utility can be a useful starting point for biological inquiry, leading to questions about the mechanisms that shaped these functions or investigations into their optimality (Legare et al., 2013). A second component of teleological thinking is the tendency to view functions as intentionally or purposefully designed (Keil, 1992; Kelemen, 1999a). This aspect of teleological thinking is often considered problematic, particularly when applied to explain the origin of biological organisms or their traits (Evans, 2008; Ware and Gelman, 2014). This component of teleological thinking reverses biological causality: rather than understanding the function of a trait to be an outcome of natural selection, the need for that function is understood to be the causal driver of a trait's existence, which in turn could support incorrect ideas about need-driven trait acquisition at the individual level.

Notice that to be problematic, teleological thinking must include both components: noticing a function as well as positioning that function as causal. However, teleological formulations vary in the extent that they explicitly link these two ideas. The statement "Chairs are for sitting" identifies a function of chairs. It could be interpreted as implying that an intentional agent designed chairs for this purpose, but it need not be interpreted this way. The statement "The reason chairs exist is for the purpose of sitting" makes the link between origin and purpose more explicit, while again implying the existence of a designer. Finally, "A designer intentionally designed chairs for sitting" explicitly invokes a designer. Similarly, the statement "Birds' wings are for flying" implies that birds' wings were designed for the purpose of flying; though again, "Birds' wings were intentionally designed for flying" is a much more explicit way to articulate the link between function and intentional design.

Because it is not possible to directly examine cognitive structures, claims about the nature and structure of teleological frameworks are inferred from teleological formulations, which can vary considerably in whether or how they make theses problematic links. Because of this ambiguity, it can be difficult to make clear inferences about cognition from how people respond to formulations, particularly when the flaws are implicit. Hence our skepticism: Would a student who agreed with the formulation "Plants produce oxygen so that animals can breathe" also agree with the formulation "Animals' need to breathe is what causes plants to produce oxygen"?

\section{Anthropocentric Thinking and Formulations}

Anthropocentric thinking describes beliefs about the central status of humans. A closely related idea, anthropomorphism, describes the belief that humans are prototypical and can therefore serve as a source from which to make analogies to other living things (Medin and Atran, 2004). Anthropocentric and anthropomorphic thinking are sometimes warranted. Humans do have an overwhelmingly impactful presence on this planet, for example. Humans can also be used as an appropriate analogy for other organisms. Young children have been shown to use human biology as a productive starting point for reasoning about other animals. For example, even though they did not know the exact nutritional needs of a pet, children reasoned that a pet might be healthier if, like humans, it was fed a varied diet (Inagaki and Hatano, 1991; Hatano and Inagaki, 1994).

The potential problem with anthropocentric thinking is in the scope of its application. One kind of error can result if humans take on too central a status in the universe, exaggerating the importance of human agency (Medin and Atran, 2004). A second (anthropomorphic) problem can occur if humans become the source for incorrect analogies, that is, if human properties, often specifically psychological properties such as consciousness, desire, or intentionality, are attributed to nonhuman entities (Carey, 1985; Tamir and Zohar, 1991; Waxman et al., 2007). Referring to animals or plants as "deciding" or "wanting" to behave in certain ways is viewed as problematic, because it can potentially impede inquiry into understanding the actual mechanisms at play.

As with teleology, anthropocentric formulations can encode multiple interpretations. For example, the statement "The heart decides how much blood is needed and adjusts accordingly" implies that the heart has cognitive capacities. However, it could also be interpreted metaphorically, with the "decision" being not literally cognitive, but an expression of the regulatory functioning of the cardiovascular system. "The heart can integrate information and make conscious decisions" is a much more explicit attribution of consciousness. Anthropocentric metaphors are common in colloquial speech and may not seem problematic to students unless the problematic implication is made obvious (Zohar and Ginossar, 1998). Similarly, anthropocentric statements are often made to emphasize, through exaggeration, the effects of human actors. It is difficult to know whether a person's claim that "humans are destroying the world" should be taken as an expression of belief or a rhetorical exaggeration. Agreement with anthropocentric formulations, therefore, is not straightforward evidence of problematic anthropocentric thinking.

\section{Essentialist Thinking and Formulations}

Essentialism refers to thinking about entities as having some ill-defined "essence" that unites them into a category (Gelman, 1988; Medin and Atran, 2004). For example, all dogs, despite superficial differences, have some dog-like essence that makes them members of the category "dogs." Further, that essence can be imagined as an internal driver that causes organisms to develop and grow in the way they do-growing tails, paws, and ears, for example (Gelman, 1988; Gelman and Wellman, 1991). Construing biological organisms in terms of essences can lead to useful expectations of continuous identity even when superficial features are changed. A swan is still a swan even if we dye it black or it loses all of its feathers. We do not need to invent new categories when superficial characteristics of organisms are altered. Essentialist thinking can also lead to expectations of continuity over developmental time. Even though puppies and adult dogs look different, they can still be considered the same species. These examples show how essentialism can help children group organisms taxonomically and provide the basis of 
early species concepts (Gelman and Markman, 1986; Gelman and Wellman, 1991). In addition, construing organisms in terms of essences sets up early expectations about continuity in lineages, providing an intuitive basis for genetic inheritance (Gelman and Wellman, 1991; Waxman et al., 2007).

Some have argued that a potential problem with essentialist thinking is that it can lead to expectations of invariance (Coley and Tanner, 2012; Diesendruck and Gelman, 1999; Shtulman, 2006; Shtulman and Schulz, 2008). The logic of this link seems to be that the idea of an essence construes organisms of a particular type as sharing characteristics. In the extreme, such thinking could lead to "essentializing" all members of a group as literally identical in many important respects. In this version of essentialism, rather than simply determining membership, essence determines trait values. Not only is there a category for swans, but we should also expect all swans to be essentially identical. This is problematic, not only because homogenizing biological variation is inaccurate, but also because understanding that natural populations vary is an important component of understanding natural selection (Samarapungavan and Wiers, 1997; Evans, 2008; Shtulman and Schulz, 2008).

Notice, however, that the potential problem with essentialism requires that the idea of an essence be linked to ideas about invariance, which need not be the case. That the concept of an innate essence would lead to ideas about invariance is actually somewhat counterintuitive, given that the idea of an essence helps form categories out of heterogeneous members. Categories like "dog" and "bird" are composed of members that look different (e.g., poodles and Labradors, swans and robins), but nevertheless share a common dog or bird essence. The shared essence supports the expectation that members of a category will share important traits in common, but need not imply invariance. The problem with essentialism is again a problem of extent of application. Ignoring variation to create a category is useful, but ignoring all variation within the category is problematic. Moreover, it matters which variation is under consideration. Some traits vary little within a category and others vary quite a bit. Distinguishing among these possibilities can create ambiguity in interpreting essentialist formulations, even those that appear explicit.

Consider an example from Coley and Tanner's (2015) study: "Apart from differences due to age and sex, members of the same species are essentially identical; any variability is biologically unimportant." This formulation includes the phrase "members of the same species are essentially identical," which could be considered a fairly explicit statement linking essentialism and species-level invariance. However, one potential source of ambiguity in interpreting this statement concerns which specific traits the reader has in mind. Because variation is trait specific (i.e., hair color varies much more than heart number), it is difficult to make inferences about cognition from responses to generic statements about "variation."

A second source of ambiguity is introduced by the clause "any variability is biologically unimportant." This clause changes the formulation from a judgment about the existence of variation to a judgment about the importance of variation. How one interprets "important" can therefore influence how one responds to this question irrespective of beliefs about the existence of biological variation. Imagine a student who considers variation to be biologically important if it can be used to make species categorizations. This student might think that variation in a trait like bill shape is important when it can be used to tell apart a finch and a mockingbird, but minor variations in bill shape among finches are unimportant. This student could reasonably agree with the above statement, thinking about within-species variation as existing but not very important, without intending to imply that every finch is exactly identical.

Our larger point is that, across all three of these categories of construals, we could find ways to interpret agreement with construal-based formulations that did not necessitate claims about students holding cognitive construal frameworks. We decided to further explore the problem in two ways. First, we revisited some of the studies from cognitive developmental psychology to better understand the original basis for claims of stable intuitive frameworks in children through adults. What we found is that many of these studies made inferences about cognitive stability from fairly limited data sets and that they often used agreement with researcher-provided statements as evidence of stable frameworks. Further, we found evidence from other work of within-individual variability and flexibility in patterns of teleological, anthropocentric, and essentialist thinking. Overall, we were unconvinced that the data supported claims of stable intuitive frameworks in individuals of any life stage.

Second, we designed and conducted a study of undergraduate biology students to explore the robustness of Coley and Tanner's (2015) results. We found that, when we changed how the prompts were presented to students, we saw lower levels of agreement. This result cannot readily be explained if students hold stable cognitive frameworks.

Overall, our purpose in this article is to use the example of cognitive construals to illustrate how a dynamic, context-sensitive perspective on cognition challenges assumptions of cognitive stability. We also aim to show how attending to context can help education researchers interpret otherwise confusing patterns in student responses. To achieve these aims, we will first summarize the differences between stable framework and dynamic perspectives on cognition and how each applies to teleological, anthropocentric, and essentialist patterns of thinking. We will then briefly review evidence from cognitive developmental psychology literature through lenses of stable interpretations and dynamic interpretations. Next, we report on the design and findings of an empirical study we designed to perturb patterns of agreement with teleological, anthropocentric, and essentialist statements. Finally, we discuss the implications of a dynamic perspective on cognition for research and instruction in biology education more broadly.

\section{CONTRASTING THEORETICAL PERSPECTIVES ON CONSTRUAL-BASED COGNITION \\ Cognitive Construals as Stable Cognitive Frameworks}

Generally, cognitive framework models propose that knowledge is internally encoded in linked structures, or frameworks (e.g., Carey, 1986; Vosniadou and Brewer, 1992; Wellman and Gelman, 1992; Samarapungavan and Wiers, 1997; Chi, 2005). These frameworks are often assumed to originate from sensible or useful interpretations of the world. However, they are thought to become problematic, because they are indiscriminately applied beyond the appropriate scope of applicability. Further, cognitive frameworks are often assumed to have some durability—they are "deeply held." Together, 
the broad and often flawed application and stability of cognitive frameworks makes them potentially problematic for learning and instruction.

Cognitive construals are described by Coley and Tanner (2012, 2015) as deeply held cognitive frameworks. They are interpretations of the world that, while useful in some contexts, can be broadly misapplied. Modeling cognitive construals as frameworks leads to several predictions about how people will interpret the world around them. The first is that people will apply construal-based thinking indiscriminately, in both correct and incorrect contexts. This argument is represented most strongly by Kelemen's "promiscuous teleology" hypotheses (Kelemen, 1999b; Kelemen and Rosset, 2009). Second, framework models propose that the ideas that make up these frameworks are coherently linked (Samarapungavan and Wiers, 1997). For example, ideas about functionality and intentionality would be linked together as part of a larger teleological framework. This assumption implies that, whenever a person reasoning with a teleological framework encounters a functional object, ideas about function will be activated along with ideas about intentional design, because the two are structurally linked. Finally, because these frameworks are structurally encoded, they will persist until they are dismantled (Vosniadou and Brewer, 1992). Framework models therefore predict that individual cognition will be relatively stable across contexts and over time until the framework is replaced.

\section{Dynamic, Context-Sensitive Alternatives}

A dynamic perspective on cognition begins from a different set of theoretical commitments, modeling knowledge as finegrained and loosely aggregated, or "knowledge-in-pieces" (diSessa, 1993; Hammer et al., 2005; Özdemir and Clark, 2007). What makes this perspective dynamic is that it holds that patterns of thinking are not predetermined by cognitive structures but instead emerge from how knowledge elements are activated in moments (diSessa, 1993, 2002; Smith et al., 1994; Thelen and Smith, 1994; Hammer, 1996; Gupta et al., 2010). Coherences and stabilities are still possible in such models if knowledge elements are repeatedly coactivated (Thelen and Smith, 1994; diSessa and Sherin, 1998). But importantly, this stability is a possible outcome, not a default assumption.

Modeling cognition dynamically allows for the possibility that expressions of teleology, for example, are in-the-moment constructions that emerge from specific contexts rather than evidence of teleological frameworks. Southerland and colleagues raised the possibility that students' use of need-based language could reflect their activation of a fine-grained knowledge element (or "p-prim," sensu diSessa, 1993) called "need as a rationale for change" (Southerland et al., 2001, p. 344). "Need as a rationale for change" simply refers to the intuition that, if an organism has a need, a change in the direction of that need would be beneficial for that organism. By itself the idea does not specify the mechanism by which the change occurs. Thus, a student who says that a plant grew toward the window "because it needs light" can be understood to be activating intuitive ideas relating change to need, but is not assumed to be proposing that the need for light itself proximally caused the change. According to a dynamic, knowledge-in-pieces model, students may have other, potentially correct ideas that they can use to fill in the mechanism if context demands (Smith et al., 1994; Hammer, 1996).
Southerland et al. (2001) found evidence of other ideas in interviews that asked students in fifth through 12th grade to explain various biological phenomena (e.g., plants growing toward light, bird plumage changing to white in the winter). While students across all grade levels frequently expressed ideas about need, many also provided mechanistic explanations in the same interview. Southerland et al. (2001) did not expect this result. They began their study from a cognitive framework perspective and therefore expected to see naïve framework-like thinking in younger students giving way to more expert-like thinking in older students. Instead, they saw students across grade levels expressing multiple ideas and moving fluidly among them. This finding led them to propose that students were constructing responses during the interview rather than calling on stable frameworks.

Ojalehto et al. (2013) proposed another theoretical explanation for apparent teleological thinking that is in line with a dynamic perspective. These authors have argued that viewing biological entities as isolated or divorced from context (e.g., a tree is just a tree) is a Western idealization that does not match how many people (including Westerners) experience the biological world. Instead, they argue that people have the capacity to understand biological entities as embedded in multiple relationships that can be viewed from multiple different perspectives (e.g., sometimes a tree is for a bird to make a home in, sometimes a tree is food for a bark beetle, sometimes a tree is for providing shade that keeps me cool). Agreeing with a statement like "Trees have bark for beetles to eat" can be an indicator of noticing a valid functional relationship. Doing so does not rule out understanding that trees play multiple ecological roles, nor does it imply that trees were shaped into existence to perform any one of these functions. Ojalehto et al. (2013) refer to this model of reasoning as "relational-deictic" to describe the capacity to see ecological relationships from multiple perspectives ("deictic" refers to the context dependency of these relationships).

These examples demonstrate how dynamic theories of cognition can account for observed patterns of thinking without assuming that those patterns come from stable cognitive frameworks. We see these alternatives as creating the need to be critical of assumptions of stable cognitive frameworks. In the next section we apply this critical lens to prior work on cognitive construals from cognitive developmental psychology to raise concerns about unexamined assumptions and methodological limitations in that work.

\section{A CRITICAL REVIEW OF PRIOR WORK IN COGNITIVE DEVELOPMENTAL PSYCHOLOGY}

Studies in cognitive developmental psychology have documented that, across a span of ages and levels of expertise, people tend to make and agree with teleological, anthropocentric, and essentialist statements that are biologically incorrect (Carey, 1985; Keil, 1992; Hatano and Inagaki, 1994; Kelemen, 1999b,c; Medin and Atran, 2004; Waxman et al., 2007). In much of this work, these observed patterns have been taken as evidence of stable frameworks that develop in early childhood and persist into adulthood (Evans, 2008; Shtulman and Schulz, 2008; Kelemen and Rossett, 2009; Kelemen et al., 2012; Ware and Gelman, 2014). We see two challenges to this interpretation. The first is a methodological critique. Some of the 
most widely cited of these studies collected data from subjects in constrained clinical contexts that could have influenced the patterns that emerged. The second challenge comes from other work that has shown evidence of variation and flexibility in thinking that is difficult to explain using stable framework models.

\section{A Methodological Critique of Prior Clinical Studies}

Many studies in cognitive developmental psychology have demonstrated that subjects will endorse or make construal-based statements in specific clinical settings. However, these patterns are not sufficient to infer that people think this way more generally outside of these, sometimes contrived, circumstances. For example, in one of the most widely cited studies by Kelemen (1999b), children were presented with pictures of various objects, both natural and artifacts (e.g., mountains, tigers, clocks), and asked a question of the form: "What is X for?" Kelemen quantified the relative frequency with which the children provided a function for the object as opposed to saying that they "did not know" or rejecting the question as "silly." The logic of the experimental design was that a large proportion of functional responses for a range of different kinds of objects would be evidence that children were indiscriminately applying a teleological mode of construing the world. Alternatively, if children often seemed confused by the question "What is X for?," then their confusion would be evidence of a more constrained application of teleological construal. Kelemen found that many children provided functional responses to a range of different objects including artifacts, parts of organisms (e.g., teeth), and whole organisms.

However, examining some of the statements provided by children in this study led us to question the validity of this interpretation. For example, when asked "What is a tiger for?," children provided answers like "A tiger is for biting" or "A tiger is for being in a zoo" (Kelemen, 1999b, p. 253). Kelemen herself wondered about how to interpret these statements. ${ }^{2}$ Do children literally believe that the reason a tiger exists is for the purpose of biting? Or that a tiger's larger purpose in life is to be in the zoo?

From a dynamic perspective, alternative interpretations of children's behavior seem more likely. One is that the context of a clinical interview influences how children respond. Children may feel the need to at least try to answer a question posed to them by an adult, even if it seems strange (Hughes and Grieve, 1980). Another possibility is that children do not understand the question in the same way that the researchers do. Hearing the question "What is a tiger for?," children may simply reinterpret the question into something less strange, like "What does a tiger do?" or "Tell me something you know about tigers." Once again, the specific context of being asked a question of the form "What is X for?" triggers certain response patterns that may not

\footnotetext{
${ }^{2}$ To address some of these concerns, a follow-up study (Kelemen, 1999b) included "pre-training" with children to attempt to ensure that they understood statements the way researchers intended. For example, the researchers presented children with an example that was meant to teach them how to think about the word "for." In the example, the researchers explained that "a pencil is for writing" but that "pencil shavings are not for anything." Again, the extent to which children under stood and then applied this specific meaning in the subsequent testing remains unclear.
}

align with how children typically think about objects. Without the ability to probe how children are interpreting the question, it is difficult to know how to interpret their answers in this study.

A third possible explanation is that children are attending to valid ecological relationships as predicted by Ojalehto et al.'s relational-deictic model (2013). This model provides an alternative interpretation for Kelemen's (1999c) finding that children more often agreed with teleological over physical explanations for natural objects when given a choice between the two. In the study, objects were presented to children within fictional ecological contexts. In one example, children were told that "all around where Mononykus lived, there was this grainy (rough) kind of sand." They were then asked, "Why do you think the sand was so grainy?" Many children selected the teleological explanation "So that animals like Mononykus could easily bury their eggs in it" over the physical explanation "Because bits of shells got broken and mixed up making it that way."

Context-dependent relational-deictic reasoning can explain this result. When presented with an ecological relationship, children may have been cued to take the perspective of Mononykus in that environment, for which grainy sand functions as a substrate in which to bury eggs. Their response about burying eggs is sensible, given that the question about sand was just presented to them from the perspective of the Mononykus creature. A relational-deictic model would further predict that, in different contexts, children might foreground different relationships. Playing with sand might invoke ideas about the usefulness of sand as a building substrate, but closely examining the color and shape of various bits of sand could cue up ideas about sand as composed of pieces of broken-up shell or rock. A dynamic perspective allows for the possibility that children can have multiple ideas about sand that can be evoked in different contexts.

Methodological constraints are also apparent in one of the most widely cited studies on essentialist thinking claiming to demonstrate that children fail to appreciate biological variation (Shtulman and Schulz, 2008). In this study, subjects were presented with a list of organismal traits and asked to comment on the likelihood that such traits exhibited or could possibly exhibit biological variation. For example, subjects were asked whether or not "all kangaroos have two stomachs," whether "all grasshoppers have green blood," or "all giraffes sleep on their feet" (Shtulman and Schulz, 2008; Table 1). Agreement with these statements was taken as evidence of an "essentialist bias" in both children and adults.

This interpretation seems inappropriate, given that many of the traits chosen by the researchers are unlikely to exhibit appreciable biological variation in natural populations. Most of these traits are critical to organismal survival and are therefore unlikely to vary. While, in principle, a mutation could cause a kangaroo to be born with a different number of stomachs, such a variant would be less likely to survive; thus, variation in a trait like stomach number is not actually likely. Nor is it biologically plausible to expect variation in the color of grasshopper blood, which is greenish because it contains hemocyanin, not hemoglobin.

Variation in behavioral traits, like giraffes sleeping standing up, is perhaps slightly more likely, as behaviors tend to be more malleable than physical traits. Sensibly, then, participants in the study were more likely to allow for variation in behavioral traits than for physical traits (Shtulman and 
TABLE 1. Original statements (from Coley and Tanner, 2015) and paired-choice statements (explicit and corrected for construals) used in our study

\begin{tabular}{|c|c|c|c|}
\hline & Original statement & Explicit statement & Corrected statement \\
\hline \multirow[t]{3}{*}{ Teleology } & $\begin{array}{l}\text { Plants produce oxygen so that animals } \\
\text { can breathe. }\end{array}$ & $\begin{array}{l}\text { Animals' need to breathe is what causes } \\
\text { plants to produce oxygen. }\end{array}$ & $\begin{array}{l}\text { Plants produce oxygen and then } \\
\text { animals are able to breathe it. }\end{array}$ \\
\hline & $\begin{array}{l}\text { Species adapt to the environment in } \\
\text { order to survive. }\end{array}$ & $\begin{array}{l}\text { The need to survive is what causes } \\
\text { species to adapt. }\end{array}$ & $\begin{array}{l}\text { Increased survival can be an outcome } \\
\text { of adaptation. }\end{array}$ \\
\hline & $\begin{array}{l}\text { Many species develop protective } \\
\text { "camouflage" to avoid predators. }\end{array}$ & $\begin{array}{l}\text { The need to avoid predators is what } \\
\text { causes species to develop protective } \\
\text { "camouflage." }\end{array}$ & $\begin{array}{l}\text { Having protective "camouflage" allows } \\
\text { species to avoid predators. }\end{array}$ \\
\hline \multirow[t]{3}{*}{ Anthropocentrism } & $\begin{array}{l}\text { Humans have caused the majority of } \\
\text { extinctions. }\end{array}$ & $\begin{array}{l}\text { Humans have caused the majority of } \\
\text { extinctions that have ever occurred } \\
\text { on Earth. }\end{array}$ & $\begin{array}{l}\text { Humans have caused some, but not the } \\
\text { majority of extinctions on Earth. }\end{array}$ \\
\hline & Plants get their food from the soil. & Plants eat soil. It is their food. & $\begin{array}{l}\text { Plants take in water and minerals from } \\
\text { the soil, but not food }\end{array}$ \\
\hline & $\begin{array}{l}\text { Competition between organisms } \\
\text { involves direct, aggressive } \\
\text { interactions. }\end{array}$ & $\begin{array}{l}\text { Competition between organisms always } \\
\text { involves some kind of direct, aggres- } \\
\text { sive, physical interactions (like } \\
\text { kicking or punching). }\end{array}$ & $\begin{array}{l}\text { Competition sometimes, but not often, } \\
\text { involves direct aggressive interac- } \\
\text { tions. }\end{array}$ \\
\hline \multirow[t]{2}{*}{ Essentialism } & $\begin{array}{l}\text { Homeostasis keeps the body static and } \\
\text { unchanging. }\end{array}$ & $\begin{array}{l}\text { If homeostasis is working properly, the } \\
\text { body cannot change. }\end{array}$ & $\begin{array}{l}\text { During homeostasis, changes in the } \\
\text { body occur. }\end{array}$ \\
\hline & $\begin{array}{l}\text { Apart from difference due to age and } \\
\text { sex, members of the same species } \\
\text { are essentially identical; any } \\
\text { variability is biologically } \\
\text { unimportant. }\end{array}$ & $\begin{array}{l}\text { Members of the same species (of the } \\
\text { same age and sex) must share } \\
\text { identical traits and characteristics. }\end{array}$ & $\begin{array}{l}\text { In addition to differences in age and } \\
\text { sex, members of the same species } \\
\text { are variable in biologically } \\
\text { important ways. }\end{array}$ \\
\hline
\end{tabular}

Schulz, 2008). That is, rather than apply blanket essentialism to the responses, subjects responded in biologically sensible ways. Overall, the patterns of rejecting variation in this study appear to be better explained by the specific prompts chosen by the researchers than a strong commitment to essentialist invariance in general.

We use these examples to illustrate how consideration of study context, for example, the phrasing and presentation of prompts, can change how evidence is interpreted. A dynamic perspective raises the need to understand how people think more generally, outside the constraints of carefully controlled, but perhaps (unintentionally) biased, clinical environments. In the next section, we review evidence from other studies that find different results when clinical constraints are lifted.

\section{Studies That Show Evidence of Variation and Flexible Thinking}

Recent work has explored how children think by using more naturalistic research methods. For example, Greif et al. (2006) presented children with various objects and asked them what questions they had. The researchers found that, in this context, children never spontaneously asked teleological questions about organisms. Concerning a tiger, they might ask, "What does it eat?," but never "What is it for?" They did, however, ask, "What is it for?" of artifacts and organism parts. This study casts further doubt on the interpretation that children are promiscuously teleological. Without prompting from researchers, children seem able to apply teleology appropriately.

A classroom study by Louca et al. (2004) provides evidence that children's teleological thinking can shift with their understanding of the kind of conversation they are having. Louca et al. (2004) describe how third-grade students having a discussion about "why leaves change color" initially provided teleological explanations (e.g., "In the winter I don't think the tree needs the leaves") along with other nonmechanistic explanations. These kinds of explanations persisted even when the teacher told them she was interested in "how" the leaves changed color, not just "why." During the discussion, the teacher 
intentionally intervened, providing an analogy to help students see the difference between how and why questions. She described baking cookies for the purpose of celebrating a birthday (why) by mixing together ingredients and baking (how). After this analogy, students began to offer ideas about mechanistic causes of leaf color change (e.g., "It has special cells that change color"). This example shows that the children were able to think about the changing colors of leaves both teleologically and mechanistically. The observed patterns in their talk were tied to their understanding of what kind of explanation was being asked for, rather than straightforward representations of their mental frameworks.

Though less well studied than teleology, children's anthropocentric reasoning and essentialist categorizing have also been found to be context dependent (for anthropocentric reasoning, see Inagaki and Hatano, 1991; Hatano and Inagaki, 1994; Gutheil et al., 1998; for essentialist categorizing, see Kalish, 2002). For example, Inagaki and Hatano (1991) described how 6-year-olds rely on anthropocentric analogies when they lack specific information about organisms. When asked what would happen to a grasshopper that was fed too much food, children would say things like "[The] grasshopper will be dizzy and die, "cause the grasshopper, though it is an insect, is like a human." In this case, children probably did not know what exactly would happen to the grasshopper, but they were able to use their knowledge of humans to make a reasonable guess. In contrast, children did not extend human properties to a grasshopper that was left behind by a caretaker. They reported knowing that, for example, unlike a human, "the grasshopper doesn't speak" (and therefore could not call out to the caretaker like a human). Here, knowledge about grasshoppers constrained children's use of human analogy. Thus, Inagaki and Hatano (1991) argue, children do not unilaterally apply human characteristics to nonhuman organisms; they make reasonable predictions when they lack detailed knowledge. The researchers suggest that as children learn more about the specifics of what organisms can and cannot do, they will be less likely to rely on humans as a source analogy.

Overall, the results of these studies demonstrate how teleological, essentialist and anthropocentric thinking emerge in flexible and often sensible patterns rather than as unconstrained biases. Moreover, these results call into question the choice to model these cognitive patterns as emerging from stable frameworks and frame the apparent stability in prior studies, at least in part, as an artifact of how the data were collected.

\section{A STUDY THAT CHALLENGES INTERPRETATIONS OF COGNITIVE STABILITY}

With these cautions in mind, we now turn to the rationale for our study, which we designed to replicate and expand upon the study conducted by Coley and Tanner (2015). Our study design, then, is relatively similar to that of the original study, in that it involves asking students to either agree or disagree with researcher-constructed statements. We believe that this study design is limited in terms of what it allows us to infer about student cognition. However, making claims about cognition was not the purpose of our study. Rather, our purpose was to test our intuition that response patterns to construal-based prompts could be perturbed if we drew students' attention toward what they implied. That is, our purpose was to attempt to falsify claims about stability rather than to make specific claims about what (or how) students were thinking when they answered these prompts. That said, we will also present some analysis of how responses differed among prompts using the context of the specific prompts to make conjectures about why some prompts elicited different response patterns.

The basic logic of our study was to first present students with more explicit or strongly worded construal formulations to cue their attention to the construal content of the original statements (see Table 1). We then compared responses in this "cued" condition with responses from students who saw the original construal statements first. Our overall research question was, "How do students' patterns of responding to and writing about construals change when cued to notice construal content?"

If students do have deeply held construal frameworks, we would expect to see high levels of agreement and endorsing of construals with an explicit cue; if construal frameworks drive their thinking, students should be more likely to agree when the implied construal logic is made more obvious. If students do not think this way, then the explicit formulations might reveal aspects of the statements that they do not intend to endorse, causing them to express opposition to the construals. We examined this question in three ways: comparing patterns of agreement with and without a cue, analyzing students' written justifications for their answers and tracking the correspondence between students' answer choices and their written responses.

\section{Study Context and Population}

A total of 262 undergraduate students at a private university in the Northeast agreed to participate in our study. All students were enrolled in an introductory biology course and participated in the study during the final week of the course. The majority of the students were first- or second-year students who had not yet declared a major. The course is required for students majoring in biology, but serves nonmajors as well.

\section{Instrument Design}

We designed an assessment instrument with two parts. The first part, mirroring the methods from Coley and Tanner (2015), included the 12 original "misconception" statements, four statements corresponding with each of the three types of cognitive construal (Table 1). Students were asked to indicate their level of agreement with these statements on a five-point Likert scale.

The second part of the assessment consisted of a pair of rephrased versions of the original statements (Table 1). One of the statements was rephrased to make the construal content of the statement more explicit. The second statement in the pair was rephrased to remove or correct the flawed construal content of the statement. For each pair, students were instructed to choose the statement they agreed with more or to choose "neither." The purpose of the paired-choice questions was to serve as a cue to draw students' attention to the construal content of the original statements. We reasoned that, when comparing explicit and corrected statements, students would notice that the salient difference between them was the construal content itself, and that this would make them more likely to notice the implied construal content in the original statements.

One version of the survey (version A) first presented participants with the original Likert questions and then presented the 
associated paired-choice questions. Version A is the "uncued" condition, because students were asked to indicate their agreement with the Likert question before encountering the pairedchoice cue. A second version (version B) first presented participants with the paired-choice questions and then presented the original Likert statements. Version B is the "cued" condition, because students were exposed to the paired statements designed to cue their attention before encountering the Likert statements. In both versions, all participants were asked to "explain their choice" in writing after the second set of questions.

\section{Data Collection}

The assessment was administered online during the final week of the Fall semester introductory biology course. Students were emailed a link to the survey and awarded a small amount of extra credit for participating.

Each individual was first randomly assigned to version A (uncued) or version B (cued) and received a survey with a random subset of six (two statements from each construal category) of the 12 statements. Thus, each of the 12 construals was administered to a random subset of the total respondents.

\section{Analysis of Agreement with Construal-Based Statements}

We calculated the number of students who agreed with each of the 12 original construal statements (Table 1) on a Likert scale (combining the data for "agree" and "strongly agree") for both version A (uncued) and version B (cued) of the assessment instrument. ${ }^{3}$ Because we were interested in comparing shifts in the number of individuals who agreed in each version of the survey, we used a chi-square test to compare count data in the cued and uncued versions. ${ }^{4}$

\section{Analysis of Written Responses}

We developed a coding scheme to analyze the content of students' written responses. Our aim was to describe the degree to which students' responses communicated the construal logic. For each question, we first read through the data and created initial categories. We noticed that, across all 12 questions, some student responses explicitly rejected or reversed the construal logic. For example, "Species did not develop camouflage in order to hide from predators." We coded these statements as rejecting the construal logic. For some statements, we noticed students rephrasing, effectively removing, the flawed construal without explicitly rejecting it. For example, "Natural selection leads to the rise of traits that help animals camouflage" removes the implication that need causes camouflage, replacing natural selection as the causal mechanism, but it does not clearly indicate that the student noticed or intended to reject the flaw in the original statement. A third category of responses preserved or endorsed the construal logic. For example, "The primary reason species develop camoflage [sic] is to evade and hide from

\footnotetext{
${ }^{3}$ Owing to an error, version B was missing one question: "Genes turn on so that cells can develop properly." We therefore have no "cued" responses to this statement.

${ }^{4}$ Note that there is some nonindependence in the data, because the subset of students who received each statement was drawn from the same pool of 262 . How ever, the random subsampling creates partial independence among subsamples. We therefore opted not to apply a Bonferroni correction for multiple nonindependent tests, though it is worth noting that doing so would put just one of the comparisons (homeostasis) below the significance threshold.
}

predators easier" preserves the link between the development of camouflage and the need to evade predators. Finally, some responses were too difficult to categorize for various reasons: some were too short or vague; some were irrelevant to the intent of the original statement; some contained a mix of phrases that could be interpreted as rejecting or removing and also preserving. All of these statements were categorized as "unclear," reflecting the fact that the coders agreed that there was insufficient information in the response to clearly assign it to any other category. Examples for each category for each of the 12 statements are provided in Table 2.

Using this coding scheme, both authors independently coded $20 \%$ of responses for each of the 12 prompts and then compared codes. Interrater reliability was consistently greater than $90 \%$, and consensus was established through discussion. A single coder (M.S.) then coded the remaining responses.

\section{Analysis of Consistency and Switching in Response Patterns}

For each version of the instrument, students responded to three prompt types: the Likert, the paired choice, and a written explanation. For each of the three, students could either endorse the construal by choosing to agree in the Likert, choosing the explicit formulation in the paired choice, or writing a response that was coded as preserving the construal. Students could oppose the construal by choosing to disagree in the Likert, choosing the corrected paired choice, and either rejecting or removing the construal logic in their written responses. Across all three prompts, there were therefore eight possible response combinations of endorsing or opposing the construal-two consistent paths and six ways to switch.

We generated diagrams that traced response patterns of individuals for all questions for both version $\mathrm{A}$ and version $\mathrm{B}$. Our aim was to determine, qualitatively, whether individuals were consistent, choosing or writing responses that always either endorsed or rejected the construal, or inconsistent, switching from endorsing to removing or rejecting the construal. For ease of analysis, we removed any individuals who chose "neither" for either the Likert or paired choice and any individuals whose written response was coded as "unclear." We then summed across individual questions to generate summary diagrams for each of the three construal types.

\section{RESULTS}

The results of our study are presented in aggregrate as well as broken down by each of the 12 statements. While we find the aggregated results to be compelling enough to raise doubts about the claim that students' thinking is generally construal based, we urge readers to consider the variation in patterns among prompts in light of our larger claim that cognition is context sensitive. Our results should not be interpreted as attempting to show that cuing unilaterally erases any agreement with construal statements. Rather, taking a dynamic, context-sensitive lens on our data draws attention to how the specifics such as word choice, explicitness, and content can possibly influence how students respond to statements. We will highlight some of the interesting qualitative patterns in these data in the Discussion of Study Results section, but to facilitate exploration of the data, we have made the raw data available publicly (Gouvea and Simon, 2018). 
TABLE 2. Examples of students' written responses coded for how they expressed the construal logic

\begin{tabular}{|c|c|c|c|c|}
\hline $\begin{array}{l}\text { Statement and } \\
\text { implication }\end{array}$ & Reject & Remove & Preserve & Unclear \\
\hline $\begin{array}{l}\text { Plants produce oxygen so } \\
\text { that animals can } \\
\text { breathe. } \\
\text { Implies that the need for } \\
\text { animals to breathe } \\
\text { causes plants to produce } \\
\text { oxygen }\end{array}$ & $\begin{array}{l}\text { "I think that the plants' } \\
\text { production of oxygen is } \\
\text { just something that } \\
\text { plants do, it is not } \\
\text { driven by animals' } \\
\text { need to breathe." }\end{array}$ & $\begin{array}{l}\text { "I believe plants produce } \\
\text { oxygen and then } \\
\text { organisms use it to } \\
\text { breathe." }\end{array}$ & $\begin{array}{l}\text { No student responses of } \\
\text { this type }\end{array}$ & $\begin{array}{l}\text { "Animals use oxygen in } \\
\text { combination with } \\
\text { glucose to produce } \\
\text { energy and carbon } \\
\text { dioxide." }\end{array}$ \\
\hline $\begin{array}{l}\text { Species adapt to the } \\
\text { environment in order } \\
\text { to survive. } \\
\text { Implies that the need to } \\
\text { survive causes } \\
\text { adaptation }\end{array}$ & $\begin{array}{l}\text { "Species do not choose to } \\
\text { adapt in order to } \\
\text { survive. Instead, the } \\
\text { simple mechanics of } \\
\text { whether an individual } \\
\text { lives or dies determines } \\
\text { the genes passed down. } \\
\text { The need to survive } \\
\text { creates the adaptation, } \\
\text { not the organism." }\end{array}$ & $\begin{array}{l}\text { "A species that can adapt } \\
\text { better or faster to its } \\
\text { environment is more } \\
\text { likely to survive." }\end{array}$ & $\begin{array}{l}\text { "Species all strive towards } \\
\text { survival and ultimately } \\
\text { reproduction. } \\
\text { Therefore, doing } \\
\text { everything physically } \\
\text { possible is in their } \\
\text { nature and therefore } \\
\text { they adapt to their } \\
\text { environment to the } \\
\text { best of their ability in } \\
\text { order to survive." }\end{array}$ & $\begin{array}{l}\text { "Depending on the } \\
\text { meaning of adaptation, } \\
\text { species can learn how } \\
\text { to cope with changing } \\
\text { situations, by changing } \\
\text { their behavior." }\end{array}$ \\
\hline $\begin{array}{l}\text { Many species develop } \\
\text { protective "camou- } \\
\text { flage" to avoid } \\
\text { predators. } \\
\text { Implies that the need to } \\
\text { develop camouflage } \\
\text { caused its development }\end{array}$ & $\begin{array}{l}\text { "Species cannot decide to } \\
\text { develop camouflage, } \\
\text { camouflage is selected } \\
\text { for because it helps } \\
\text { them avoid predators." }\end{array}$ & $\begin{array}{l}\text { "Camouflage' is a result of } \\
\text { mutations that better } \\
\text { mask the prey from } \\
\text { their predators." }\end{array}$ & $\begin{array}{l}\text { "The primary reason } \\
\text { species develop } \\
\text { camoflage [sic] is to } \\
\text { evade and hide from } \\
\text { predators easier." }\end{array}$ & $\begin{array}{l}\text { "Because evolutionary } \\
\text { science" }\end{array}$ \\
\hline $\begin{array}{l}\text { Genes turn on so that a } \\
\text { cell can develop } \\
\text { properly. } \\
\text { Implies that the need to } \\
\text { develop properly causes } \\
\text { genes to turn on }\end{array}$ & $\begin{array}{l}\text { "Cells don't have a 'need' } \\
\text { to develop properly. If } \\
\text { they happen to develop } \\
\text { properly, they are not } \\
\text { happier than if they } \\
\text { were to develop } \\
\text { improperly." }\end{array}$ & $\begin{array}{l}\text { "A cell can't develop } \\
\text { correctly without the } \\
\text { proper code and } \\
\text { directions. These come } \\
\text { from genes. When the } \\
\text { gene is on the cell can } \\
\text { develop the right way } \\
\text { by following the } \\
\text { directions for } \\
\text { development the gene } \\
\text { codes for." }\end{array}$ & $\begin{array}{l}\text { "A cell cannot develop } \\
\text { properly or specify } \\
\text { without specific genes } \\
\text { turning on. Genes turn } \\
\text { on with the end } \\
\text { purpose of proper } \\
\text { development of cells." }\end{array}$ & $\begin{array}{l}\text { "I don't understand this } \\
\text { idea of genes turning } \\
\text { on." }\end{array}$ \\
\hline $\begin{array}{l}\text { Homeostasis keeps the } \\
\text { body static and } \\
\text { unchanging. } \\
\text { Implies that, because of } \\
\text { homeostasis, the body } \\
\text { does not change }\end{array}$ & $\begin{array}{l}\text { "Homeostasis is the body's } \\
\text { way of adjusting to any } \\
\text { outside changes. The } \\
\text { body needs to change } \\
\text { to maintain equilib- } \\
\text { rium." }\end{array}$ & $\begin{array}{l}\text { "The body is at homeosta- } \\
\text { sis at most times but } \\
\text { can still grow and } \\
\text { change." }\end{array}$ & $\begin{array}{l}\text { "Homeostasis keeps the } \\
\text { body temperature, } \\
\text { blood pressure, etc. the } \\
\text { same without regards } \\
\text { to the environment it is } \\
\text { surrounded by." }\end{array}$ & $\begin{array}{l}\text { "Energy is still used in } \\
\text { homeostasis." }\end{array}$ \\
\hline $\begin{array}{l}\text { Apart from difference due } \\
\text { to age and sex, } \\
\text { members of the same } \\
\text { species are essentially } \\
\text { identical; any } \\
\text { variability is biologi- } \\
\text { cally unimportant. } \\
\text { Implies that species are } \\
\text { essentially invariant }\end{array}$ & $\begin{array}{l}\text { "Variation among individu- } \\
\text { als in a population is } \\
\text { essential for eventual } \\
\text { evolution of a species." }\end{array}$ & $\begin{array}{l}\text { "Members of the same } \\
\text { species can differ in } \\
\text { ways other than age } \\
\text { and sex, like in } \\
\text { coloring/patterning of } \\
\text { skin or fur. I don't have } \\
\text { enough information to } \\
\text { say whether or not } \\
\text { such differences would } \\
\text { be biologically } \\
\text { important or not." }\end{array}$ & $\begin{array}{l}\text { "Variations don't really } \\
\text { matter in the big } \\
\text { picture." }\end{array}$ & $\begin{array}{l}\text { "I honestly think it } \\
\text { depends of [sic] the } \\
\text { species, and the } \\
\text { observers['] knowledge } \\
\text { of the species. To me, } \\
\text { all humans look } \\
\text { different, all dogs look } \\
\text { different. But all } \\
\text { squirrels look the same } \\
\text { to me. But I know a lot } \\
\text { more about humans } \\
\text { than I know about } \\
\text { squirrels." }\end{array}$ \\
\hline
\end{tabular}


TABLE 2. Continued

\begin{tabular}{|c|c|c|c|c|}
\hline $\begin{array}{l}\text { Statement and } \\
\text { implication }\end{array}$ & Reject & Remove & Preserve & Unclear \\
\hline $\begin{array}{l}\text { Different cells in an } \\
\text { organism (e.g., skin, } \\
\text { muscle, nerve) contain } \\
\text { different DNA. } \\
\text { Implies that DNA must be } \\
\text { different to determine } \\
\text { different cellular } \\
\text { functions }\end{array}$ & $\begin{array}{l}\text { "All cells contain the same } \\
\text { DNA, they just differ by } \\
\text { which genes are } \\
\text { expressed." }\end{array}$ & $\begin{array}{l}\text { "They just express them } \\
\text { differently." }\end{array}$ & $\begin{array}{l}\text { "Everything has a different } \\
\text { function, and if shape } \\
\text { determines function, } \\
\text { then the shape/ } \\
\text { sequence of DNA must } \\
\text { be different." }\end{array}$ & $\begin{array}{l}\text { "Mutations could probably } \\
\text { occur that give them } \\
\text { the same sequence." }\end{array}$ \\
\hline $\begin{array}{l}\text { Without outside influ- } \\
\text { ences, ecological } \\
\text { communities will } \\
\text { remain stable } \\
\text { indefinitely. } \\
\text { Implies that ecological } \\
\text { communities are } \\
\text { essentially static }\end{array}$ & $\begin{array}{l}\text { "Outside factors influence } \\
\text { an ecological } \\
\text { community. They're } \\
\text { rarely consistently } \\
\text { stable because } \\
\text { everything is intercon- } \\
\text { nected and they rely on } \\
\text { so many other } \\
\text { organisms." }\end{array}$ & $\begin{array}{l}\text { "Organisms die and are } \\
\text { born. Species can } \\
\text { migrate to other } \\
\text { locations. These are } \\
\text { examples of changes } \\
\text { that could happen in } \\
\text { ecological community." }\end{array}$ & $\begin{array}{l}\text { "Ecological communities } \\
\text { stay stable through } \\
\text { their own processes." }\end{array}$ & “ex. predator-prey graphs" \\
\hline $\begin{array}{l}\text { Humans have caused the } \\
\text { majority of extinctions. } \\
\text { Implies that human agency } \\
\text { is overly important }\end{array}$ & $\begin{array}{l}\text { "The earth has existed far } \\
\text { longer than humans } \\
\text { have inhabited it. } \\
\text { Humans are probably } \\
\text { only a partial cause of } \\
\text { a TINY portion of } \\
\text { earth's extinctions." }\end{array}$ & $\begin{array}{l}\text { "Other factors, such as } \\
\text { predators and lack of } \\
\text { resources, can cause } \\
\text { extinction." }\end{array}$ & $\begin{array}{l}\text { "Directly or indirectly, } \\
\text { we've definitely caused } \\
\text { a large number of } \\
\text { extinctions. (record } \\
\text { numbers, I read this in } \\
\text { an article some- } \\
\text { where)." }\end{array}$ & $\begin{array}{l}\text { "Some extinctions are } \\
\text { natural occurrences." }\end{array}$ \\
\hline $\begin{array}{l}\text { Plants get their food from } \\
\text { the soil. } \\
\text { Implies the plants, like } \\
\text { humans, eat food }\end{array}$ & $\begin{array}{l}\text { "Plants do not eat in the } \\
\text { same way humans do. } \\
\text { They absorb nutrients } \\
\text { through the soil, but do } \\
\text { not digest and } \\
\text { consume soil." }\end{array}$ & $\begin{array}{l}\text { "They get their energy } \\
\text { from the sun, } \\
\text { molecules to store } \\
\text { energy from air and } \\
\text { soil (water) and } \\
\text { nutrients from soil." }\end{array}$ & $\begin{array}{l}\text { "Plants use soil to obtain } \\
\text { nutrients, i.e., soil is } \\
\text { their food." }\end{array}$ & $\begin{array}{l}\text { "Plants need to get their } \\
\text { form of energy some } \\
\text { how." }\end{array}$ \\
\hline $\begin{array}{l}\text { Competition between } \\
\text { organisms involves } \\
\text { direct, aggressive } \\
\text { interactions. } \\
\text { Implies that all or most } \\
\text { organisms are, like } \\
\text { humans, aggressive }\end{array}$ & $\begin{array}{l}\text { "Species often compete for } \\
\text { resources, which is } \\
\text { rarely direct." }\end{array}$ & $\begin{array}{l}\text { "There are so many other } \\
\text { types of competition. } \\
\text { ex. food competition, } \\
\text { living space competi- } \\
\text { tion, mating competi- } \\
\text { tion." }\end{array}$ & $\begin{array}{l}\text { "Aggression is always in } \\
\text { ecosystems because } \\
\text { organisms must fight } \\
\text { for limited resources." }\end{array}$ & $\begin{array}{l}\text { "This is evident from the } \\
\text { behavior of living } \\
\text { things to survive." }\end{array}$ \\
\hline
\end{tabular}

\section{Patterns of Agreement with Original Statements in Cued versus Uncued Conditions}

For the teleological statements (Figure 1), we found relatively high levels of agreement with the original misconception statements (Table 1) when students were uncued. For example, more than $75 \%$ of students agreed with the Species Adapt and Camouflage questions, and more than 30\% agreed with the Plants Oxygen question. In contrast, we found that, for three of the four teleological statements, students who were cued first were significantly less likely to agree (Plants Oxygen, $\chi^{2}=$ 54.53, $n=51, d f=5$; Species Adapt, $\chi^{2}=56.13, n=58, d f=5$;
Camouflage, $\chi^{2}=69.91, n=53, d f=5$ ). No data were available for the cued version of the Genes question.

For the anthropocentric statements (Figure 2), when students were uncued, we found varying levels of agreement with the original misconception statements (Table 1), ranging from about $25 \%$ for the Extinctions question to greater than $80 \%$ for the Competition question. For all four statements, students were less likely to agree when first cued with the paired-choice question; this difference was significant in three of four statements (with the difference in the Extinctions prompt not statistically significant; competition, $\chi^{2}=152.99$, 


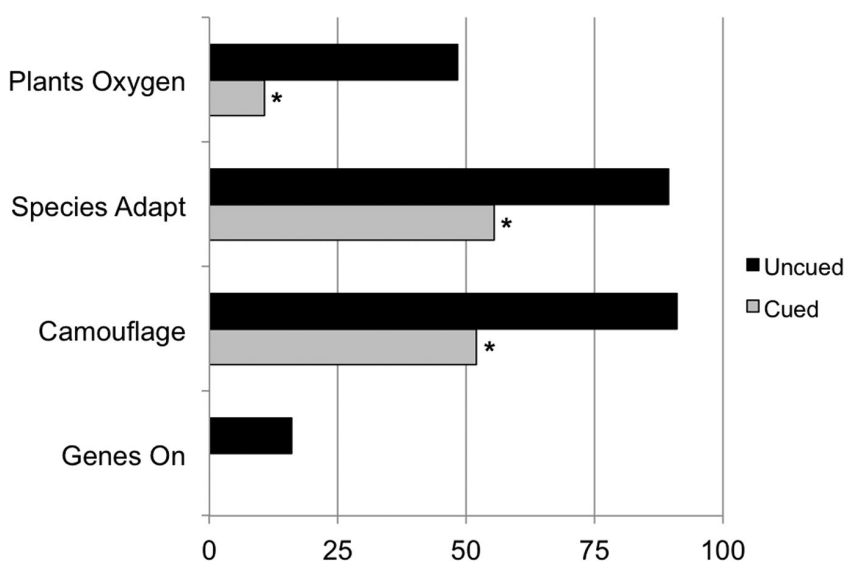

FIGURE 1. Percent agreement with teleological construal statements in uncued Likert and cued Likert conditions. Counts were compared using a chi-square test; *, $p<0.05$. Owing to a technical issue with the online instrument, no data were collected for Genes version B (cued). Version A participants (uncued) agreed with the statement $16 \%$ of the time $(n=56)$.

$n=62, d f=5$; Heart Decides, $\chi^{2}=37.92, n=62, d f=5$; Plants Eat, $\chi^{2}=9.73, n=62, d f=5$; Extinctions, $\chi^{2}=4.04, n=57$, $d f=5)$.

For the essentialist statements (Figure 3), students were less likely to agree with the original misconception statements (Table 1 ) in the uncued condition than for the other two construal categories (less than 50\% agreement for all questions). The Homeostasis statements followed a pattern similar to the other two construals, with higher levels of agreement in the uncued condition and significantly less agreement in the cued condition $\left(\chi^{2}=41.11, n=61, d f=5\right)$. For two statements, DNA Cells and Variation, we found low levels of agreement (less than $20 \%$ ) in both uncued and cued conditions. Differences were not statistically significant. The Ecosystems question showed the reverse trend, with statistically more students agreeing in the cued condition than in the uncued condition $\left(\chi^{2}=37.27, n=\right.$ $61, d f=5)$.

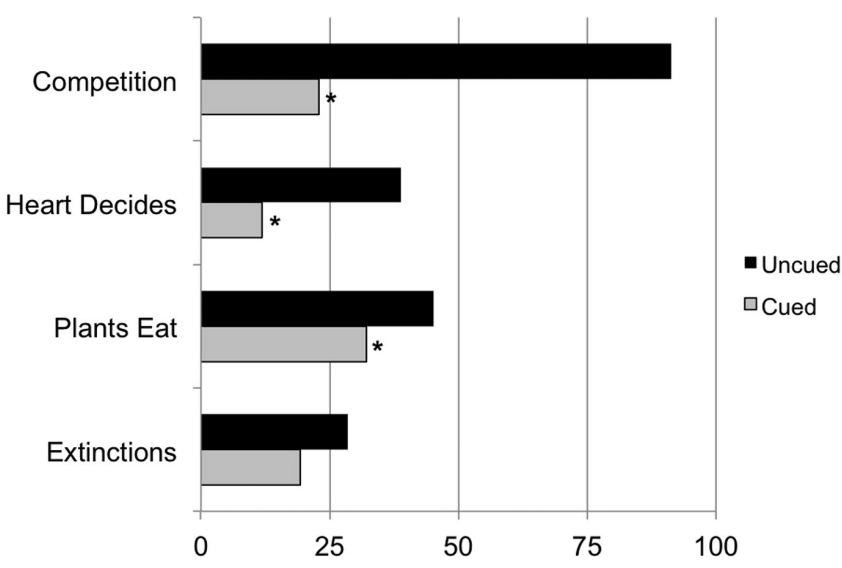

FIGURE 2. Percent agreement with anthropocentric construal statements in uncued Likert and cued Likert conditions. Counts were compared using a chi-square test; ${ }^{*}, p<0.05$.

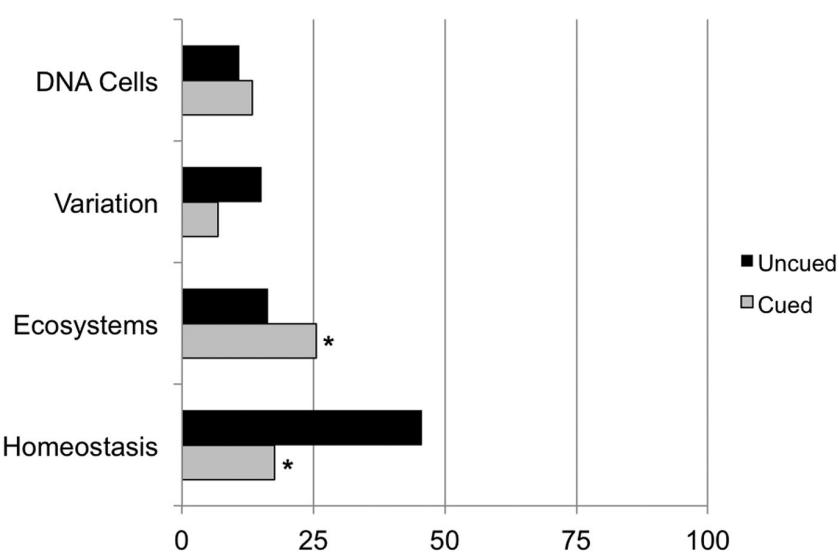

FIGURE 3. Percent agreement with essentialist construal statements in uncued Likert and cued Likert conditions. Counts were compared using a chi-square test; ${ }^{*}, p<0.05$.

\section{Construal Content in Written Responses}

Our analysis of written responses involved describing how students' formulations treated the problematic logic of each construal type (Table 2). A summary of these responses by prompt is presented in Table 3. Across all questions, students' written responses most often reflected explicit rejection of the construal content ( $43 \%$ on average), communicating that they noticed the flaw and did not intend to endorse it. An additional 34\% of students wrote written responses in which they removed the problematic nature of the implied construal. Fifteen percent of students' responses could not be unambiguously categorized, and only $8 \%$ of responses on average contained any evidence of preserving the problematic construal logic.

Written responses reflected rejection or removal most often for essentialism and least often for teleology. Responses that preserved construal logic occurred most often for teleology and least often for essentialism.

The proportion of students who rejected, removed, and preserved the implied construal varied from question to question within each construal category (Table 3 ). For example, zero responses preserved the construal in the Plants Oxygen and Heart Decides questions, while greater than 20\% and 13\% preserved the flaws in the Species Adapt and Plants Eat questions, respectively.

\section{Patterns of Consistency and Switching in Individual Response Paths}

In this section, we describe the response patterns for respondents who took versions A and B. Diagrams depicting how individuals' responses shifted for each question are provided in the Supplementary Material (Supplemental Figures S1-S3). Because of the similarity in response patterns within each construal type, we describe the patterns for each construal in aggregate (Figure 4, a-c).

In version A, students were initially uncued. As predicted, once cued, many students switched from endorsing to opposing the construal. For teleological (Figure 4a) and anthropocentric (Figure 4b) construal types, students initially agreed more than they disagreed in the Likert questions. More than 50\% of these respondents shifted from initial agreement with the construal 
TABLE 3. Frequency (in percent) of types of qualitative responses for each prompt, combining versions $A$ and $B$

\begin{tabular}{|c|c|c|c|c|c|}
\hline & Reject & Remove & Preserve & Unclear & $N$ \\
\hline \multicolumn{6}{|l|}{ Teleology } \\
\hline Plants produce oxygen so that animals can breathe. & 58.8 & 34.2 & 0 & 7.0 & 114 \\
\hline Species adapt in order to survive. & 24.1 & 34.8 & 20.5 & 20.5 & 112 \\
\hline Many species develop protective "camouflage" to avoid predators. & 28.7 & 36.1 & 11.1 & 24.1 & 108 \\
\hline Genes turn on so that a cell can develop properly. & 26.0 & 44.0 & 12.0 & 18.0 & 50 \\
\hline Mean & 34.4 & 37.3 & 10.9 & 17.4 & \\
\hline \multicolumn{6}{|l|}{ Anthropocentrism } \\
\hline Humans have caused the majority of extinctions. & 62.3 & 14.0 & 6.1 & 17.5 & 114 \\
\hline Plants get their food from the soil. & 34.5 & 44.5 & 13.6 & 7.3 & 110 \\
\hline $\begin{array}{l}\text { The heart decides how much blood is needed throughout the body and } \\
\text { adjusts the rate at which it beats accordingly. }\end{array}$ & 39.3 & 44.7 & 0 & 17.9 & 117 \\
\hline Competition between organisms involves direct, aggressive interactions. & 25.4 & 56.1 & 5.3 & 13.2 & 114 \\
\hline Mean & 40.4 & 39.8 & 6.3 & 14.0 & \\
\hline \multicolumn{6}{|l|}{ Essentialism } \\
\hline Homeostasis keeps the body static and unchanging. & 49.6 & 36.3 & 8.0 & 6.2 & 113 \\
\hline $\begin{array}{l}\text { Without outside influences, ecological communities will remain stable } \\
\text { indefinitely. }\end{array}$ & 46.4 & 22.7 & 8.2 & 22.7 & 110 \\
\hline $\begin{array}{l}\text { Apart from differences due to age and sex, members of the same species are } \\
\text { essentially identical; any variability is biologically unimportant. }\end{array}$ & 40.5 & 39.6 & 8.1 & 11.7 & 111 \\
\hline $\begin{array}{l}\text { Different cells in an organism (e.g., skin, muscle, nerve) contain different } \\
\text { DNA. }\end{array}$ & 80.7 & 0.9 & 4.4 & 14.0 & 114 \\
\hline Mean & 57.1 & 33.6 & 7.2 & 14.1 & \\
\hline Overall mean & 43.0 & 34.0 & 8.1 & 15.0 & \\
\hline Overall SD & 17.5 & 15.0 & 5.8 & 6.1 & \\
\hline
\end{tabular}

statement to choosing the corrected construal in the paired choice (first set of downward arrows). The most dramatic example of this pattern is the large proportion (nearly 50\%) of students who initially agreed with the statement "Plants produce oxygen so that animals can breathe," but universally avoided the statement "The reason plants produce oxygen is so that animals can breathe it" (no students who chose "agree" chose the explicit construal; Supplemental Figure S1). Students tended not to agree with essentialist prompts initially, even without cuing (Figure 4c). Nevertheless, more than $50 \%$ of students switched once cued in version $\mathrm{A}$.

A smaller number of respondents switched to rejecting or removing the construal in their written responses after both agreeing with the construal statement in the Likert question and choosing the more explicit construal in the paired choice (second set of downward arrows) (Figure 4, a-c). The net effect of this switching in all three construal types is that most of the students who initially agreed with the construal statement either rejected or removed it in their written responses. That is, overall levels of endorsement decreased as students proceeded through the three questions (decreasing size of white circles).

In contrast, very few respondents (at most five within essentialism) in version A switched from disagreeing with the construal to later endorsing or accepting it (upward arrows) (Figure 4 , a-c). Most of the respondents who initially disagreed with the construal statement continued to show evidence of opposing the construal by choosing the corrected construal in the paired choice and rejecting or removing the construal language in their written responses (horizontal black arrows). The net effect is an increasing number of responses that oppose the construal across the prompts for all construal types (increasing size of black circles).

In version $\mathrm{B}$, respondents first answered the paired-choice question and were more likely to initially choose the corrected construal over the explicitly flawed construal statement (Figure 4, a-c). If students chose the corrected statement, they tended to continue to oppose the construal, disagreeing with the Likert statement and rejecting or removing the flawed construal logic in their written responses (black horizontal arrows).

Some students who took version B switched from opposing the construal to later endorsing it (black upward arrows) (Figure 4, a-c). Roughly $10 \%$ of students who initially chose the corrected choice in the pair, switched to agreeing in the Likert question (first set of upward arrows). Many of these switchers, switched again, rejecting or removing the construal in their written responses (second set of downward arrows). The net pattern shows once again that overall endorsement decreases and overall opposition increases across the prompts in both versions $\mathrm{A}$ and $\mathrm{B}$.

\section{DISCUSSION OF STUDY RESULTS}

Coley and Tanner (2015) claimed that agreement with and corresponding expressions of construal phrasing in written responses was evidence that construal-based frameworks drive thinking in biology undergraduates. Our findings challenge this interpretation in three ways. First, we found that students cued with explicit construal formulations were less likely to agree 
(a)

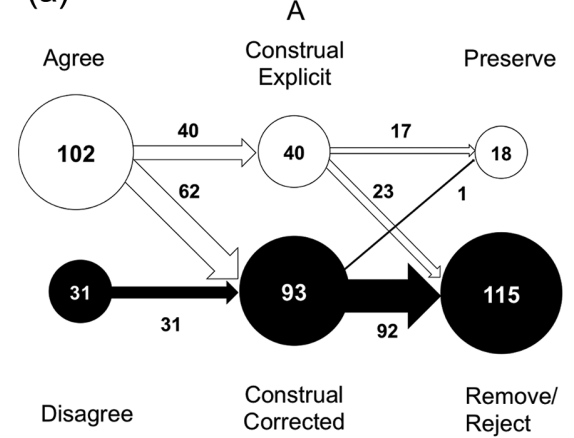

Teleology

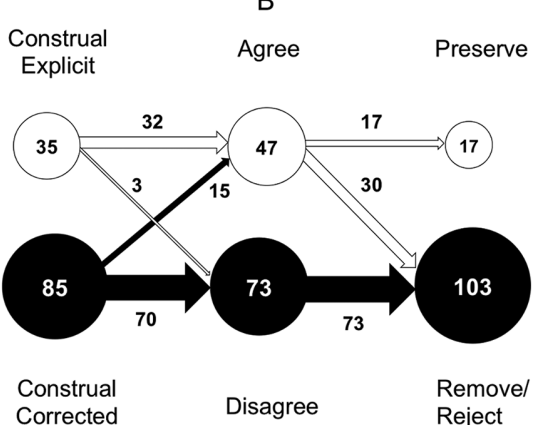

(b)

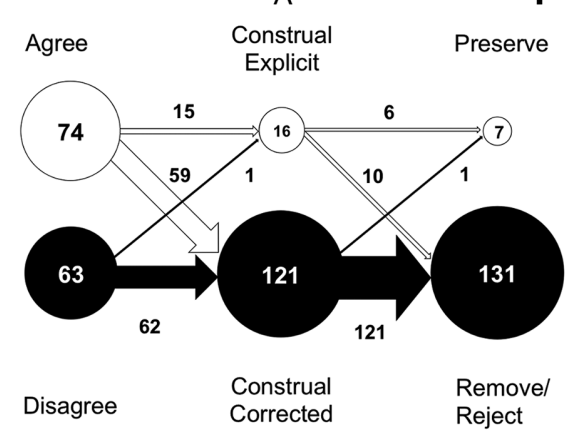

B

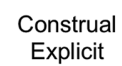

Agree

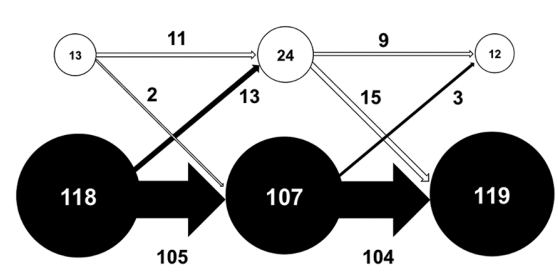

Construal Corrected

formulations initially, with a large proportion of these students choosing the corrected statement and removing or rejecting the problematic construal content in their written responses. A framework model of cognitive construals cannot easily explain these results, most simply because such a model would not predict that more explicit construal formulations (or any context-specific effects) would change patterns of agreement. To explain these patterns, we need to look more carefully at how context may be influencing student responses.

In the remainder of this section we discuss how dynamic, context-sensitive models can offer possible explanations for our results, and we provide an alternative interpretation of Coley and Tanner's (2015) original data. We specifically address possible context-sensitive explanations for three patterns: 1) students' initial agreement with misconception statements (in our study and in Coley and Tanner's original study), 2) the lower percentage of agreement in cued versus uncued students in our study, and 3) students who continued to express agreement even with cuing in our study.

(c)

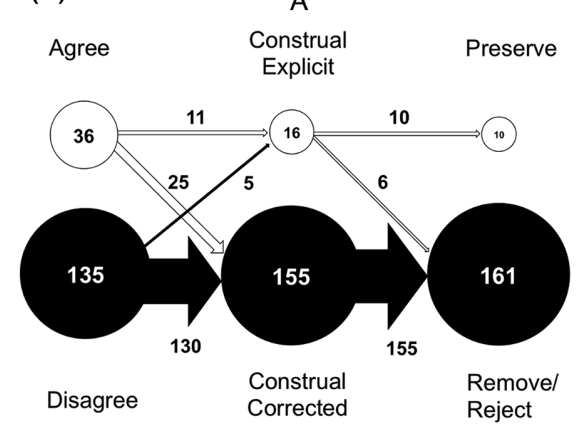

\section{Essentialism}

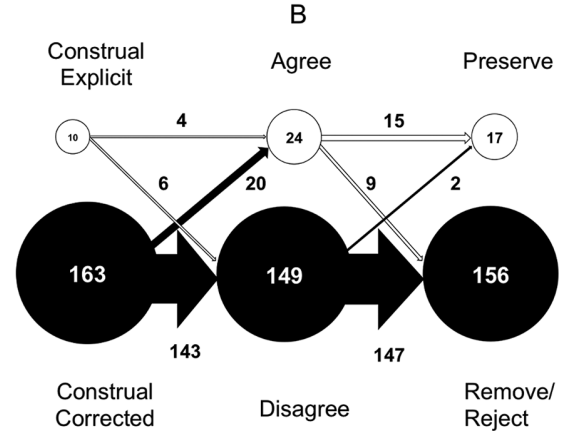

FIGURE 4. Path diagrams tracing number of individuals through each of three prompts for (a) teleology, (b) anthropocentrism, and (c) essentialism. White circles indicate number of responses that endorse (chose "agree" in Likert and/or amplified construal in paired choice) or express acceptance of construal in written response. Black circles indicate number of responses that oppose (chose "disagree" in Likert and/or corrected construal in paired choice) or reject or remove construal in written responses. Size of circles scaled to number of respondents. Arrows indicate number of respondents following each response path scaled to the number of respondents. Downward arrows show number of respondents switching from endorsing to rejecting construal. Upward arrows show number of respondents switching from rejecting to endorsing construal. Horizontal arrows show number of students who are consistent in either endorsing or rejecting construal across prompts.

with the original misconception statements than those who were not cued. Second, we found very low levels of construal-preserving language in written responses; instead, after seeing both sets of questions, students overwhelmingly rejected or removed the problematic formulations. Third, we found patterns of switching in students who agreed with the construal

\section{Explaining Initial Agreement with Construal-Based Formulations}

Like Coley and Tanner (2015), we found relatively high levels of initial agreement with many of the original 12 statements, especially those that were teleological and anthropocentric (Figures 1-3). In this section, we consider various aspects of context that could explain this pattern.

Students May Have Been Agreeing with Valid Biological Relationships. In our description of teleology, anthropocentrism, and essentialism, we discussed how each type of construal is a collection of ideas, some of which are valid and some of which can be problematic. Teleology, for example, includes valid ideas about function along with problematic ideas about intentionality. Ojalehto et al. (2013) proposed that a tendency to notice valid functional relationships among organisms could explain agreement with teleological formulations without committing people to the flawed causality.

Recognizing and agreeing with valid biological relationships could explain some of the initial agreement with teleological statements we found in undergraduates. For example, agreement with statements like "Plants produce oxygen so that animals can breathe" may reflect students taking on a relational perspective. Viewed from the perspective of animals, a 
function of plants is to produce the oxygen they need to breathe. Additional support for this interpretation comes from students' written responses. For this statement, all students either rejected or removed the teleological causality in their written explanations (Table 3). At the same time, most acknowledged the valid functional dependency, writing, for example, "Oxygen is a byproduct of the photosynthesis reaction. Animals do not force plants to undergo photosynthesis, but they benefit from it." 5 This response, which was written by a student who initially agreed with the misconception statement before the forced choice, rejects the idea that animals caused ("forced") plants to produce oxygen. Yet it acknowledges the validity of relationship by stating both that plants produce oxygen and that animals benefit.

Similarly, many students acknowledged the relationship between adaptation and survival generally, and camouflage and predator avoidance specifically, without agreeing that need was the causal driver in either case. Instead, in line with Southerland et al. (2001), students often appeared to use the idea of need to indicate the potential benefits of adapting. For example, "as the natural selection of species took place, those animals that could adapt and have camouflage were the ones who survived-thus there was a need for them to adapt." While this student's response includes the phrase "there was a need for them to adapt," there is no evidence of flawed causality here. "Need" refers to the beneficial consequence of adapting, not the cause.

The general idea that students may be attending to valid ideas can also explain agreement with anthropocentric and essentialist statements. For example, initial agreement with "The heart decides how much blood is needed throughout the body and adjusts the rate at which it beats accordingly" could reflect noticing the role the heart plays in regulating blood flow and failing to notice the anthropocentric implication that the heart does this consciously. Agreement with the statement "Homeostasis keeps the body static and unchanging" could indicate attention to the function of homeostasis, to keep body conditions within a narrow range, without agreement with the essentialist implication that the body is maintained in a constant invariant state.

Within each of the 12 statements, it is possible to find sensible biological interpretations, and we argue that one explanation for student agreement with these statements is that they may have noticed and agreed with such interpretations.

Students May Have Agreed Because They Lacked or Misapplied Specific Knowledge. Another possible source of agreement with initial statements could stem from a lack or a misapplication of specific knowledge. For example, rather than agreeing with the statement "Humans have caused the majority of extinctions" because of anthropocentrism, students may not have known, remembered, or correctly applied the relevant

\footnotetext{
${ }^{5}$ We have opted not to conduct a full analysis of students' written responses because it was not our purpose to make claims about what students were thinking as they responded to these statements. As we explain in the Implications for Research on Student Cognition section, we think there are better methods for addressing those questions. Our purpose here is to use examples of students' written responses to illustrate the plausibility of interpretations other than those that claim students are reasoning from stable construal frameworks. We also include a link (https://doi .org/10.7910/DVN/YCXJ6Q) to the full data set for interested readers.
}

facts about extinctions. There is evidence that this may have been the case for some students. For example,

I don't know the exact figure, but I believe human-induced habitat changed [sic] has caused $80 \%$ of all extinctions. In just a couple centuries, we have destroyed half the world's forests, and over a hundred species go extinct daily (if I'm recalling my trivia correctly). Although previous mass extinctions were enormous, humans have managed to kill off more animals through habitat destruction over a period of a couple hundred years.

This student was attempting to use facts ( $80 \%$ of all extinctions) to answer the question, but appears to be applying this statistic incorrectly, using it to support the claim that current extinctions outnumber past extinctions. Other students who agreed with the original statement also cited correct evidence about human-induced effects like habitat destruction or climate change to support their agreement, but may have been applying these ideas incorrectly.

Agreement Due to Confusion or Misinterpretations of Initial Statements. A third source of initial agreement may have stemmed from difficulties interpreting some of the original prompts. Continuing with the extinction example above, it appears that students may have been confused about how to interpret the statement "Humans have caused the majority of extinctions," because it does not specify a time period. The statement could be interpreted as true if one is considering recent history, but is not true over longer geological periods. It is difficult to know for sure how students were interpreting this statement, but our point again is only that misinterpretation is a possible alternative explanation. This casts doubt on the conclusion that students are anthropocentric thinkers more generally.

A similar issue may explain the relatively high proportion of initial agreement (greater than 90\%) with "Competition between organisms involves direct, aggressive interactions." For the other three anthropocentric statements, uncued agreement was less than 50\% (Figure 2). Like the Extinctions statement, the Competition statement is vague-it does not specify with what frequency competition is direct and aggressive. Therefore, it would have been reasonable for a student to agree, even if he or she only meant that some instances of competition are direct (which is true). The large drop-off in agreement (27 out of 30 of respondents in version A agreed and then removed/ rejected; Supplemental Figure S2) combined with students' tendency to specify frequency in their written responses (e.g., "Some interactions are aggressive, but most probably aren't.") support this interpretation.

Another statement that seemed to cause confusion for students was "Without outside influences, ecological communities are essentially stable." Some students explicitly expressed their confusion over how to interpret the clause "without outside influences." One student wrote, "Ecological systems are almost always influenced by outside factors, so it is difficult to determine what would actually happen if there were no outside influencers." Another wrote, "Although impossible to get rid of outside influences (for example I consider the sun an influence). If everything were to stay constant there would be no 
reason for it to change." This example illustrates the difficulty in deciding what should count as an influence that is "outside" an ecosystem, because ecosystems are not closed systems. In this instance, the student chose to agree with the statement, appealing to the hypothetical scenario in which all influences could be removed, but appears to correctly understand that ecosystems are not static.

That some students may not understand prompts in the way researchers intend is part of the methodological challenge of trying to make inferences about cognition from patterns of responses to multiple-choice or short-answer questions. Just as children may be confused when they are asked, "What is a tiger for?," undergraduates in this study may have been confused about what the questions they were being asked were really trying to get at. We elaborate on how to address this research challenge in the Implications for Research on Student Cognition section.

\section{Explaining Lower Levels of Agreement in Cued Students}

Students who were cued first (version B) agreed less with the original misconception statements than uncued students (version A) in seven of 11 cases (Figures 1-3). This result suggests that many students are not stably committed to what those statements imply — their tendency to agree can be perturbed by the cue. We examine two possible mechanisms for how the cue may have changed response patterns.

Cuing Drew Students' Attention to the Flaw in Initial Statements. One interpretation is that the cuing statements drew students' attention to the flawed implication in the original statements that they otherwise may have missed. This interpretation builds on the explanation that initial agreement may have occurred because students saw the valid, but not the flawed, implication of the misconception statements. When the problematic nature of the statement was highlighted, students could see past the valid relationship to notice and often reject the flaw. Each of the more explicitly worded teleological cuing statements (Table 1), for example, calls out the flawed needbased causality. That students noticed and rejected this flaw is supported by their rejection of it in written responses like "Plants do not produce oxygen with the sole purpose of supporting animals," "Species do not choose to adapt," or "It's not correct to say they develop the camouflage for a definite purpose."

Noticing the flaw could have also reduced agreement with anthropomorphic prompts that falsely attributed human characteristics to the heart, plants, or competition (Table 1). For example, for the Heart Decides statement, the explicit prompt highlighted the incorrect attribution of decision making to the heart. In written statements, students rejected this idea, writing responses like "The heart doesn't make informed decisions."

While agreement with essentialist statements was generally lower than with teleological or anthropocentric statements, cuing may have drawn students' attention to the flawed implication of a static unchanging body in the Homeostasis statement specifically. Those responses coded as "rejecting" the essentialism for this prompt rejected the idea that homeostasis literally meant that the body would not change at all. For example, "Homeostasis just means that processes and conditions are in balance, not that they are static." Some students also described change as a normal part of homeostatic regulation, writing statements such as "The body needs to change to maintain equilibrium."

Students Were Alerted to the Absurdity of the Cuing Statements. Another possible explanation is that students saw the cuing statements as obviously wrong or absurd, and this caused them to reject the original statements as well. We will briefly explore that possibility using the example of the cuing statement "Plants eat soil, it is their food," a more absurd version of the statement "Plants get their food from the soil."

A student who took version B of the survey would encounter the more absurd prompt first. That student might then reject the statement "Plants get their food from the soil" to avoid any association with the implication that plants literally eat soil. While we cannot completely rule out this possibility, we do not think it is a likely explanation for most students. If the only reason for disagreeing with the original prompt was to avoid association with "Plants eat soil," we would expect written responses to only reflect rejection of that absurdity (i.e., plants do not eat soil). We do not see these types of responses. Very few students even bothered to dispute the idea that plants eat soil. Instead, most made arguments about plants getting "food" through photosynthesis. Other students, apparently attending to the valid idea that plants do get something from the soil, emphasized that it is not "food" but "nutrients" that plants absorb from the soil.

We have provided two possible mechanisms by which the cue would have altered response patterns: it may have specifically drawn students' attention to the flawed teleological, anthropocentric, or essentialist content or more generally caused students to read the misconceptions statements more critically. Either way, that a cue could change patterns of agreement challenges the claim that students are generally reasoning using stable teleological, anthropocentric, or essentialist frameworks.

\section{Explaining Patterns of Agreement Despite Cuing}

In our data, a small subset (about $10 \%$ on average) of students consistently chose to agree, chose the incorrect paired choice, and then wrote a response that preserved the construal implication (Figure 4, a-c). As we have explained, factual errors, confusion or even valid thinking can explain some of this endorsement. Could stable flawed frameworks explain some of it?

We do not believe a clear answer is supported by our data. If we consider individual student responses, even the strongest endorsements of the construal logic do not provide a clear picture of what students are thinking. To illustrate this challenge, consider the response "Species have an innate drive to survive, and therefore lack of resources or a change in the environment will cause them to produce offspring that favor the environmental changes." This response states that the "drive to survive" causes species to produced better-adapted offspring. But what does this statement allow us to infer about what the student is thinking? Does the student believe that, when faced with adverse conditions, organisms can willfully produce offspring that will be favored under those conditions? It seems unfair to come to this conclusion without first asking some basic follow-up questions (e.g., How would they produce better-adapted 
offspring?). Nor does this single response tell us much about whether this student would use need-based reasoning more generally. We would want more data about how this student is thinking about related scenarios.

We happen to have data on how this particular student responded to the related Camouflage question. This student received version A of the survey and initially agreed with the statement "Many species develop protective 'camouflage' to avoid predators." Later, this student chose the corrected choice "Having protective 'camouflage' allows species to avoid predators" over "The need to avoid predators is what causes species to develop protective "camouflage."' Finally, the student wrote in explanation of this choice, "Camoflauge [sic] protects species from predators because they have adapted and it increases their chances of survival." In this response, we no longer see evidence of need-based inheritance that we saw in the species example. As written, the development of camouflage seems to precede, not follow from, survival. So what does this student "really" think? Our larger point is that thinking is not the straightforward expression of structures in the mind; it is an act of construction, building from knowledge that is activated and assembled in particular situations. To understand that process, we need research methods that attend to how the particularities of context influence the patterns of thinking that emerge.

\section{IMPLICATIONS FOR RESEARCH ON STUDENT COGNITION}

Our main purpose in this article has been to argue from a dynamic, context-sensitive perspective on cognition. Taking this view creates both a challenge and an opportunity for biology education researchers. The challenge, as we have attempted to illustrate with the example of cognitive construals, arises from the realization that instances of incorrect statements may not tell us very much about the nature of student cognition more generally (Smith et al., 1994). This challenge points to a research opportunity-investigating the dynamics of students' thinking. If students' thinking can be influenced by context, then we can investigate when and how.

Recent work in biology and chemistry education has begun to examine some of the effects of context on student thinking. Some studies have found that different content examples can cue up different patterns of thinking for students (e.g., Teichert et al., 2008; Taber and García-Franco, 2010; Talanquer, 2010; Nehm and Ha, 2011). For example, Talanquer (2010) found that, within the general content area of colligative properties, students were more likely to use teleological language to explain the phenomenon of osmosis (e.g., "the water needs to reach equilibrium") but more likely to use mechanistic language to explain the phenomenon of boiling point elevation (e.g., "the salt has stronger bonds that need to be broken"). Both phenomena are related to the concentrations of molecules or ions in solution, yet in one case, students largely ignored molecular-level entities, and in the other case, students referred to molecular-level mechanisms in their explanations. This phenomenon-level variation suggests that undergraduates are not unilaterally teleological in their chemistry thinking, but that the specifics can matter for what ideas they bring to bear.

A recent study by Hubbard et al. (2017) examined how the format and structure of assessments can influence the ideas students share. These authors compared the ideas students endorsed in multiple true-false formats with the ideas they wrote in open-ended responses. They found that students shared fewer ideas in their written responses than they were willing to choose in the multiple true-false. This pattern was true for both correct and incorrect ideas. This result raises interesting questions about what to infer about students' cognition from different assessment formats. On the one hand, multiple true-false formats provide more information about the ideas students are willing to choose. However, this format could be prompting students to make choices that are not representative of how they think all, or even most, of the time. On the other hand, open-ended response formats may elicit ideas that are more salient to students, but these assessments risk missing ideas that students do not choose (or are not cued) to share. From a dynamic perspective, neither is strictly more diagnostic; each method measures thinking under different conditions, providing different information about how students are thinking.

The variation in student thinking patterns described by these studies highlights the need to study biological thinking as a dynamic process that unfolds in interaction with the surrounding environment. An important area for future research is to understand these dynamics by expanding the unit of analysis to include minds "situated" in contexts (e.g., Greeno, 1997; Bang, 2015; Saxe et al., 2015). Such work will require a greater focus on methods that study individuals across contexts and over longer periods of time.

\section{IMPLICATIONS FOR BIOLOGY INSTRUCTION}

One implication of the argument against stable frameworks for biology instruction is that deeply held cognitive construals are not likely to be a problem that instructors need to spend time addressing. Students may initially agree with teleological, anthropocentric, or essentialism statements, but we find it unlikely that students are strongly committed to these lines of thinking.

A second implication is to consider how the context of assignments or tasks influence student thinking and to be conscious of these effects in instructional design. In the classroom conversation about leaves changing color, Louca et al. (2004) posited that students did not provide mechanistic explanations because they did not see the need to. This suggests that instructors may need to provide more guidance about what kinds of explanations are expected and what counts as a mechanistic explanation. As the Louca et al. (2004) study illustrates, thirdgrade students can attend to mechanism once they understand this to be the kind of conversation they are having.

The amount and nature of guidance needed to support students in attending to mechanism may differ by phenomenon. Returning to the chemistry example from Talanquer (2010), it seems clear that students are capable of reasoning about molecular mechanisms, but they may need additional support knowing how and when to apply molecular-level ideas to a particular phenomenon like osmosis.

A dynamic view of cognition emphasizes how the challenge of instruction can change, sometimes in unexpected ways, as the specifics of the learning environment change (e.g., Hammer, 1996). Once again, this can viewed as an opportunity to understand how to design learning contexts to draw out latent patterns of productive thinking from students. 


\section{CONCLUSION}

Building on a trajectory of work in cognitive developmental psychology, Coley and Tanner $(2012,2015)$ proposed that a general feature of human cognition, cognitive construals, could explain a variety of common difficulties observed in biology classrooms. We offer an alternative interpretation of these difficulties - that they are reflective of the context sensitivity of student cognition. In this, we build on a growing body of research suggesting that human cognition is generally dynamic and sensitive to context. We argue that a much-needed area for future research in biology education should involve new theoretical work and new methodological approaches aimed at understanding these dynamics and their impacts on learning and instruction in biology.

\section{ACKNOWLEDGMENTS}

We thank Lara Appleby, Ezra Gouvea, Robert Hayes, Shane Jordan, and Aditi Wagh for comments and conversations that improved this article. We are also grateful to Eric Kuo for encouraging work in this direction. Finally, we thank two anonymous reviewers for comments and suggestions that greatly improved the article.

\section{REFERENCES}

Bang, M. (2015). Culture, learning, and Development and the natural world: The influences of situative perspectives. Educational Psychologist, 50(3), $220-233$.

Carey, S. (1985). Conceptual change in childhood. Cambridge, MA: MIT Press.

Carey, S. (1986). Cognitive science and science education. American Psychologist, 41(10), 1123-1130.

Chi, M. T. H. (2005). Commonsense conceptions of emergent processes: Why some misconceptions are robust. Journal of the Learning Sciences, 14(2), 161-199.

Coley, J. D., \& Tanner, K. D. (2012). Common origins of diverse misconceptions: Cognitive principles and the development of biology thinking. CBE-Life Sciences Education, 11(3), 209-215. https://doi.org/10.1187/ cbe.12-06-0074

Coley, J. D., \& Tanner, K. D. (2015). Relations between intuitive biological thinking and biological misconceptions in biology majors and nonmajors. CBE-Life Sciences Education, 14(1), ar8. https://doi.org/10.1187/ cbe.14-06-0094

Diesendruck, G., \& Gelman, S. A. (1999). Domain differences in absolute judgments of category membership: Evidence for an essentialist account of categorization. Psychonomic Bulletin \& Review, 6(2), 338-346. http:// doi.org/10.3758/BF03212339

diSessa, A. A. (1993). Toward an epistemology of physics. Cognition and Instruction, 10(2), 105-225. https://doi.org/10.1207/s1532690xci1002

diSessa, A. A. (2002). Why "conceptual ecology" is a good idea. In Limon, M., \& Mason, L. (Eds.), Reconsidering conceptual change: Issues in theory and practice (pp. 29-60). Boston: Kluwer Academic.

diSessa, A. A., \& Sherin, B. L. (1998). What changes in conceptual change? International Journal of Science Education, 20(10), 1155-1191.

Evans, E. M. (2008). Conceptual change and evolutionary biology: A developmental analysis. In Vosniadou, S. (Ed.), International handbook of research on conceptual change (pp. 263-294). New York: Routledge.

Gelman, S. A. (1988). The development of induction within natural kind and artifact categories. Cognitive Psychology, 20(1), 65-95. https://doi .org/10.1016/0010-0285(88)90025-4

Gelman, S. A., \& Markman, E. M. (1986). Categories and induction in young children. Cognition, 23(3), 183-209. https://doi.org/10.1016/0010 -0277(86)90034-X.

Gelman, S. A., \& Wellman, H. M. (1991). Insides and essences: Early understandings of the non-obvious. Cognition, 38, 213-244.
Gouvea, J., \& Simon, M. (2018). Cognitive construals in biology. https://doi.org 10.7910/DVN/YCXJ6Q, Harvard Dataverse, V1, UNF:6:CSALPrEu2Bx9 FWycTTQSOW= =

Greeno, J. G. (1997). On claims that answer the wrong questions. Educational Researcher, 26(1), 5-17. https://doi.org/10.3102/0013189X026001005

Greif, M. L., Kemler Nelson, D. G., Keil, F. C., \& Gutierrez, F. (2006). What do children want to know about animals and artifacts? Domain-specific requests for information. Psychological Science, 17(6), 455-459. https:// doi.org/10.1111/j.1467-9280.2006.01727.x

Gupta, A., Hammer, D., \& Redish, E. F. (2010). The case for dynamic models of learners' ontologies in physics. Journal of the Learning Sciences, 19(3), $285-321$.

Gutheil, G., Vera, A., \& Keil, F. C. (1998). Do houseflies think? Patterns of induction and biological beliefs in development. Cognition, 66, 33-49.

Hammer, D. (1996). Misconceptions or p-prims: How may alternative perspectives of cognitive structure influence instructional perceptions and intentions. Journal of the Learning Sciences, 5(2), 97-127.

Hammer, D., Elby, A., Scherr, R. E., \& Redish, E. F. (2005). Resources, framing, and transfer. In Mestre, J. P. (Ed.), Transfer of learning from a modern multidisciplinary perspective (pp. 89-120). Greenwich, CT: Information Age.

Hatano, G., \& Inagaki, K. (1994). Young children's naive theory of biology. Cognition, 50(1-3), 171-188.

Hubbard, J. K., Potts, M. A., \& Couch, B. A. (2017). How question types reveal student thinking: An experimental comparison of multiple-true-false and free-response formats. CBE-Life Sciences Education, 16(2), ar26. http:// doi.org/10.1187/cbe.16-12-0339

Hughes, M., \& Grieve, R. (1980). On asking children bizarre questions. First Language, 1(2), 149-160.

Inagaki, K., \& Hatano, G. (1991). Constrained person analogy in young children's biological inference. Cognitive Development, 6(2), 219-231. https://doi.org/10.1016/0885-2014(91)90037-E

Kalish, C. W. (2002). Essentialist to some degree: Beliefs about the structure of natural kind categories. Memory \& Cognition, 30(3), 340-352. https:// doi.org/10.3758/BF03194935

Keil, F. C. (1992). The origins of an autonomous biology. In Gunnar, M. R., \& Maratsos, M. (Eds.), Modularity and constraints in language and cognition (Minnesota symposia on child psychology, Vol. 25) (pp. 103-137). Mahwah, NJ: Erlbaum.

Kelemen, D. (1999a). Function, goals and intention: Children's teleological reasoning about objects. Trends in Cognitive Sciences, 3(12), 461-468. https://doi.org/10.1016/S1364-6613(99)01402-3

Kelemen, D. (1999b). The scope of teleological thinking in preschool children. Cognition, 70(3), 241-272. https://doi.org/10.1016/S0010 -0277(99)00010-4

Kelemen, D. (1999c). Why are rocks pointy? Children's preference for teleological explanations of the natural world. Developmental Psychology, 35(6), 1440-1452. https://doi.org/10.1037/0012-1649.35.6.1440

Kelemen, D., \& Rosset, E. (2009). The human function compunction: Teleological explanation in adults. Cognition, 111(1), 138-143. https://doi org/10.1016/j.cognition.2009.01.001

Kelemen, D., Rottman, J., \& Seston, R. (2012). Professional physical scientists display tenacious teleological tendencies: Purpose-based reasoning as a cognitive default. Journal of Experimental Psychology: General, 142(4), 1074-1083. https://doi.org/10.1037/a0030399

Legare, C. H., Lane, J. D., \& Evans, E. M. (2013). Anthropomorphizing science: How does it affect the development of evolutionary concepts? MerrilPalmer Quarterly, 59(2), 168-197. https://doi.org/10.1353/mpq.2013.0009

Leonard, M. J., Kalinowski, S. T., \& Andrews, T. C. (2014). Misconceptions yesterday, today, and tomorrow. CBE-Life Sciences Education, 13(2) 179-186. http://doi.org/10.1187/cbe.13-12-0244

Louca, L. T., Elby, A., Hammer, D., \& Kagey, T. (2004). Epistemological resources: Applying a new epistemological framework to science instruction. Educational Psychologist, 39(1), 57-68. https://doi org/10.1207/s15326985ep3901_6

Maskiewicz, A. C., \& Lineback, J. E. (2013). Misconceptions are "So yesterday!" CBE-Life Sciences Education, 12(3), 352-356. https://doi org/10.1187/cbe.13-01-0014 
Medin, D. L., \& Atran, S. (2004). The native mind: Biological categorization and reasoning in development and across cultures. Psychological Review, 111(4), 960-983. https://doi.org/10.1037/0033-295X.111.4.960

Nehm, R. H., \& Ha, M. (2011). Item feature effects in evolution assessment. Journal of Research in Science Teaching, 48(3), 237-256. https://doi .org/10.1002/tea.20400

Ojalehto, B. L., Waxman, S. R., \& Medin, D. L. (2013). Teleological reasoning about nature: Intentional design or relational perspectives? Trends in Cognitive Sciences, 17(4), 166-171. https://doi.org/10.1016/j.tics.2013 .02 .006

Özdemir, G., \& Clark, D. B. (2007). An overview of conceptual change. Eurasia Journal of Mathematics, Science \& Technology Education, 3(4), $351-361$.

Samarapungavan, A., \& Wiers, R. W. (1997). Children's thoughts on the origin of species: A study of explanatory coherence. Cognitive Science, 21(2), 147-177.

Saxe, G. B., de Kirby, K., Kang, B., Le, M., \& Schneider, A. (2015). Studying cognition through time in a classroom community: The interplay between everyday and scientific concepts. Human Development, 58, 544

Shtulman, A. (2006). Qualitative differences between naive and scientific theories of evolution. Cognitive Psychology, 52(2), 170-194. http://doi .org/10.1016/j.cogpsych.2005.10.001\&;iuml; \&;iuml;

Shtulman, A., \& Schulz, L. (2008). The relation between essentialist beliefs and evolutionary reasoning. Cognitive Science, 32(6), 1049-1062. https://doi.org/10.1080/03640210801897864

Smith, J. P., DiSessa, A. A., \& Roschelle, J. (1994). Misconceptions reconceived: A constructivist analysis of knowledge in transition. Journal of the Learning Sciences, 3(2), 115-163. https://doi.org/10.1207/ s15327809jls0302_1

Southerland, S. A., Abrams, E., Cummins, C. L., \& Anzelmo, J. (2001). Understanding students' explanations of biological phenomena: Conceptual frameworks or p-prims. Science Education, 85(4), 328-348. https://doi org/10.1002/sce.1013
Taber, K. S., \& García-Franco, A. (2010). Learning processes in chemistry: Drawing upon cognitive resources to learn about the particulate structure of matter. Journal of the Learning Sciences, 19(1), 99-142. https:// doi.org/10.1080/10508400903452868

Talanquer, V. (2010). Exploring dominant types of explanations built by general chemistry students. International Journal of Science Education, 32(18), 2393-2412. https://doi.org/10.1080/09500690903369662

Talanquer, V. (2013). When atoms want. Journal of Chemical Education, 90(11), 1419-1424. https://doi.org/10.1021/ed400311x

Tamir, P., \& Zohar, A. (1991). Anthropomorphism and teleology in reasoning about biological phenomena. Science Education, 75(1), 57-67. https:// doi.org/10.1002/sce.3730750106

Teichert, M. A., Tien, L. T., Anthony, S., \& Rickey, D. (2008). Effects of context on students' molecular-level ideas. International Journal of Science Education, 30(8), 1095-1114. https://doi.org/10.1080/09500690701355301

Thelen, E., \& Smith, L. B. (1994). A dynamic systems approach to the development of cognition and action. Cambridge, MA: MIT Press.

Vosniadou, S., \& Brewer, W. (1992). Mental models of the earth: A study of conceptual change in childhood. Cognitive Psychology, 585(24), 535585

Ware, E. A., \& Gelman, S. A. (2014). You get what you need: An examination of purpose-based inheritance reasoning in undergraduates, preschoolers, and biological experts. Cognitive Science, 38(2), 197-243. https:// doi.org/10.1111/cogs.12097

Waxman, S. R., Medin, D. L., \& Ross, N. (2007). Folkbiological reasoning from a cross-cultural developmental perspective: Early essentialist notions are shaped by cultural beliefs. Developmental Psychology, 43(2), 294-308. https://doi.org/10.1037/0012-1649.43.2.294

Wellman, H. M., \& Gelman, S. A. (1992). Cognitive development: Foundational theories of core domains. Annual Review of Psychology, 43, 337-375.

Zohar, A., \& Ginossar, S. (1998). Lifting the taboo regarding teleology and anthropomorphism in biology education-heretical suggestions. Science Education, 82, 679-697. https://doi.org/10.1002/(SICI)1098 $-237 X(199811) 82: 6<679:: A I D-S C E 3>3.0 . C O ; 2-E$ 